\title{
Description of $\mathrm{CD8}^{+}$Regulatory $\mathrm{T}$ Lymphocytes and Their Specific Intervention in Graft-versus-Host and Infectious Diseases, Autoimmunity, and Cancer
}

\author{
Martha R. Vieyra-Lobato, ${ }^{1}$ Jorge Vela-Ojeda, ${ }^{1,2}$ Laura Montiel-Cervantes, ${ }^{1,2}$ \\ Rubén López-Santiago, ${ }^{1}$ and Martha C. Moreno-Lafont $\mathbb{C}^{1}$ \\ ${ }^{1}$ Departamento de Inmunología y Departamento de Morfología, Escuela Nacional de Ciencias Biológicas, Instituto Politécnico \\ Nacional, Prolongación de Carpio y Plan de Ayala S/N, Colonia Santo Tomás, Miguel Hidalgo, 11340 CDMX, Mexico \\ ${ }^{2}$ Unidad Médica de Alta Especialidad, Centro Médico Nacional La Raza, Instituto Mexicano del Seguro Social, Seris y Zaachila S/N, \\ Colonia La Raza, Atzcapotzalco 02990 CDMX, Mexico
}

Correspondence should be addressed to Martha C. Moreno-Lafont; mmlafont@gmail.com

Received 3 March 2018; Revised 9 May 2018; Accepted 6 June 2018; Published 5 August 2018

Academic Editor: Eyad Elkord

Copyright (c) 2018 Martha R. Vieyra-Lobato et al. This is an open access article distributed under the Creative Commons Attribution License, which permits unrestricted use, distribution, and reproduction in any medium, provided the original work is properly cited.

\begin{abstract}
Gershon and Kondo described $\mathrm{CD} 8^{+}$Treg lymphocytes as the first ones with regulating activity due to their tolerance ability to foreign antigens and their capacity to inhibit the proliferation of other lymphocytes. Regardless, CD8 ${ }^{+}$Treg lymphocytes have not been fully described-unlike $\mathrm{CD} 4^{+}$Treg lymphocytes-because of their low numbers in blood and the lack of specific and accurate population markers. Still, these lymphocytes have been studied for the past 30 years, even after finding difficulties during investigations. As a result, studies have identified markers that define their subpopulations. This review is focused on the expression of cell membrane markers as CD25, CD122, CD103, CTLA-4, CD39, CD73, LAG-3, and FasL as well as soluble molecules such as FoxP3, IFN- $\gamma$, IL-10, TGF- $\beta$, IL-34, and IL-35, in addition to the lack of expression of cell activation markers such as CD28, CD127 CD45RC, and CD49d. This work also underlines the importance of identifying some of these markers in infections with several pathogens, autoimmunity, cancer, and graft-versus-host disease as a strategy in their prevention, monitoring, and cure.
\end{abstract}

\section{Introduction}

In general, $\mathrm{CD}^{+}$Treg lymphocytes have been characterized as a heterogeneous population consisting of lymphoid cells that express certain surface markers depending on their inhibition activity and the microenvironment they are found in [1].

In 1970, Gershon and Kondo described $\mathrm{CD}^{+}$Treg lymphocytes for the first time when they published the results of experiments using mice. The study described a population of lymphocytes from bone marrow responsible for tolerance. These cells were originally called "suppressor T lymphocytes." In their work, the researchers proved the cross-reactivity of related antigens by immunizing mice, first using sheep erythrocytes and then horse erythrocytes.
The treatment induced tolerance to horse red blood cells in mice that had been immunized with high levels of sheep red blood cells. This tolerance was proven to be mediated by thymic cells [2]. They later proved the regulatory role of peripheral thymocytes, specifically those located in the spleen [3]. The study of these cells was further developed in 2007 under the concept of $\mathrm{CD}^{+}$Treg cells in the context of some viral infections and development of some tumors. These works established the indirect importance of IFN- $\gamma$ in the induction of their regulatory activity through molecules as indoleamine 2,3-dioxygenase (IDO) [4].

It is currently known that $\mathrm{CD} 8^{+}$Treg lymphocytes have an inhibitory effect through soluble factors or cell-cell contact. In murine and human models, different works have described a number of regulatory mechanisms mediated by 


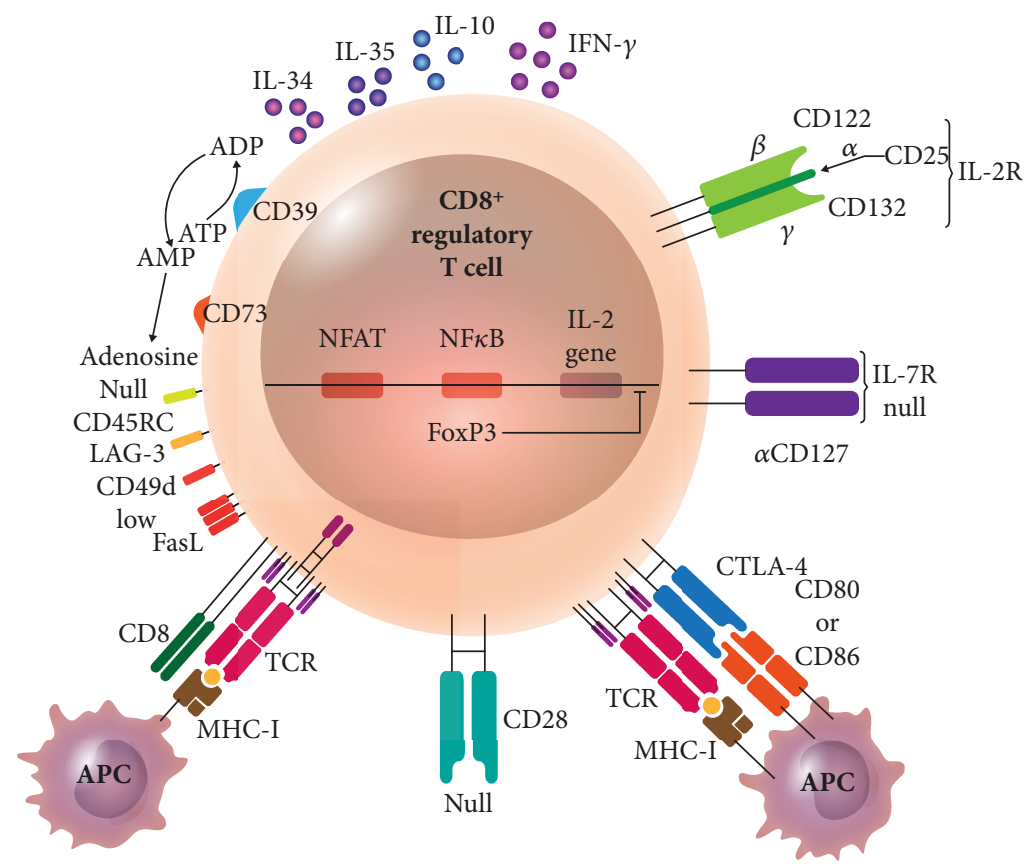

Figure 1: $\mathrm{CD} 8^{+}$Treg lymphocyte. $\mathrm{CD} 8^{+}$Treg lymphocytes have different suppression mechanisms of cell activation and survival, using their own molecule expression: IL-2 receptor $\alpha$-chain (CD25), IL-2 and IL-15 receptor $\beta$-chains (CD122), inhibitory receptor CD152 or CTLA-4, ectoenzymes CD39 and CD73 degrading ATP to ADP (CD39) and AMP to adenosine (CD73), an MHC-II-binding molecule called LAG-3 (lymphocyte activation gene-3), and the apoptosis-inducing molecule FasL. This T cell subset expresses low or absent costimulatory receptor CD28 and the IL-7 receptor $\alpha$-chain (CD127), the cellular activation molecule CD45RC, and the integrin CD49d and releases cytokines as IL-10, IL-34, IL35, and IFN- $\gamma$; transcription factor FoxP3 inhibits IL-2 gene transcription. APC: antigen-presenting cell; CTLA-4: cytotoxic T-lymphocyte antigen 4.

$\mathrm{CD}^{+}$Treg lymphocytes: (a) direct death of target cell $[5,6]$, (b) negative signaling through CTLA-4 or PD1 when interacting with the antigen-presenting cell [7], and (c) release of immunosuppressive cytokines as IL-10 and TGF$\beta[8,9]$. The suppressor effect is evident when $\mathrm{CD}^{+}$Treg lymphocytes are able to inhibit the proliferation of effector $\mathrm{CD}^{+}$and $\mathrm{CD}^{+}$effector T lymphocytes [10]. The immunosuppressive effect of $\mathrm{CD}^{+}$Treg lymphocytes is likely to be beneficial by reducing the severity of the inflammatory response present during the development of the graftversus-host disease (GVHD) or autoimmune diseases. On the other hand, it would be beneficial to decrease the CD8 ${ }^{+}$ Treg population in diseases such as cancer or infections where they participate in the evasion of the immune response. Proving this effect would shed light on its application as preventive or healing cell therapy.

The expression of surface molecules acting as cell markers helps to phenotypically identify $\mathrm{CD}^{+}$Treg lymphocytes. Phenotypic markers include the high expression of the IL-2 receptor $\alpha$-chain CD25 and expression of CD122 (IL-2 and IL-15 receptor $\beta$-chains), adhesion molecule CD103, ectoenzymes CD39 and CD73, the inhibition receptor CD152 or CTLA-4 (cytotoxic T lymphocyte-associated molecule-4), an MHC-II-binding molecule called LAG-3, and the apoptosisinducing molecule FasL. The soluble molecules that $\mathrm{CD} 8^{+}$ Treg lymphocytes can express are FoxP3, IFN- $\gamma$, IL-10, IL34, and IL-35. The absence of activation markers is also studied when looking for $\mathrm{CD}^{+}$Treg lymphocytes. The costimulation molecule CD28, the IL-7 receptor $\alpha$-chain (known as
CD127), the cell activation molecule CD45RC, and the integrin CD49d are absent or show low expression [10] (Figure 1).

1.1. Surface Markers of CD $8^{+}$Treg Lymphocytes. The overexpression of CD25, widely described in CD $4^{+}$Treg lymphocytes, indicates the presence of a regulatory activity, inhibiting the proliferation of effector lymphocytes in competition for IL-2. Given the high expression of CD25 in the membrane of Treg lymphocytes, the latter obtain most of the cytokine, leaving effector T lymphocytes without the supply of this growth factor. For its part, marker CD25 is commonly sought together with transcription factor FoxP3 [11]. In $\mathrm{CD}^{+}$Treg lymphocytes, it is unclear whether CD25 subtracts IL-2 from the medium as a regulatory mechanism. However, $\mathrm{CD} 8{ }^{+} \mathrm{CD} 25^{+}$Tregs are present in both human and mouse and are very sensitive to IL-2 to proliferate compared to $\mathrm{T}$ effectors and capable of inhibiting the proliferation of effector $\mathrm{T}$ cells [12].

On the other hand, a subset of $\mathrm{CD}^{+} \mathrm{CD} 122^{+}$Treg lymphocytes in mice has been observed to be efficient in the suppression of allogeneic, autoimmune, and antitumor responses. Additionally, $\mathrm{CD} 8{ }^{+} \mathrm{CD} 122^{+} \mathrm{T}$ cells express large amounts of IL-15 receptor $\alpha$-chain (IL-15RA). The $\beta$ (CD122) and $\gamma$ - (CD132) chains are overexpressive and common for CD25 and IL-15R $\alpha$; however, CD25 is absent in those cells. Therefore, the distinctive molecule is CD122 and not CD25. That is why these lymphocytes consume IL-15 to proliferate and not IL-2 [13]. The expression of CD122 is associated with memory lymphocytes [13, 14]. 
Because nonregulatory memory lymphocytes can also express $\mathrm{CD} 122$, the presence of $\mathrm{PD}-1$ is evaluated to confirm that it is $\mathrm{CD} 8^{+} \mathrm{CD} 122^{+}$Treg [15]. Apparently, TCR-MHC-I is a mechanism of interaction between these lymphocytes and the target cells [16], and $\mathrm{CD} 8^{+} \mathrm{CD} 122^{+}$cells regulate through IL-10 [17].

When $\mathrm{CD} 8^{+} \mathrm{CD} 122^{+} \mathrm{T}$ cells are eliminated from mice, there is a growth of specific tumor T cells and infiltration of effector/memory $\mathrm{T}$ cells in the tumor $[15,18]$. In mice, marker CD122 is exclusive of $\mathrm{CD}^{+}$Treg lymphocytes and is absent from $\mathrm{CD}^{+} \mathrm{CD} 25^{+}$Treg lymphocytes [19]. CD122 works as an IL-15 receptor, which promotes survival and proliferation of $\mathrm{CD}^{+}$Treg lymphocytes, so that the transfer of $\mathrm{CD}^{+} \mathrm{CD}^{-} 22^{+} \mathrm{T}$ lymphocytes, along with the administration of recombinant IL-15, promotes its regulatory activity, extending the survival of mice after pancreas transplant [18]. Indeed, in mice, CD122 has made a difference between $\mathrm{CD}^{+}$and $\mathrm{CD}^{+}$Treg lymphocytes since, as it has been already stated, the first often express high levels of CD25 while the latter exhibit elevated levels of CD122. For their part, $\mathrm{CD} 8^{+} \mathrm{CD} 122^{+}$Treg lymphocytes are related to the success of allogeneic transplant via the induction of apoptosis among alloeffector $\mathrm{T}$ lymphocytes and thus inhibiting transplant rejection [20].

In mice, $\mathrm{CD} 8^{+} \mathrm{CD} 122^{+} \mathrm{T}$ cells are comparable with $\mathrm{CD}^{+}{ }^{+} \mathrm{CXCR}^{+}{ }^{+} \mathrm{T}$ cells in humans since they release IL- 10 and suppress IFN $-\gamma$ production by $\mathrm{CD}^{+}{ }^{+} \mathrm{CXCR} 3^{-}$effector $\mathrm{T}$ cells [21].

Also known as LFA-1, CD103 is an adhesion molecule present in $\mathrm{T}$ lymphocytes bound to E-cadherin from the parenchymal epithelial tissue or mucous membranes. This molecule promotes retention of Treg lymphocytes in such tissues in areas expressing E-cadherin where the regulation of immune response is needed. This is highly useful to identify $\mathrm{CD}^{+}$Treg lymphocyte subpopulations according to their location [22]. It must be considered that molecule $\mathrm{CD} 103$ does not provide an exclusive regulatory function to $\mathrm{CD}^{+}$Treg lymphocytes given that $\mathrm{CD}^{+}$effector $\mathrm{T}$ lymphocytes also express it $[23,24]$.

Ectoenzymes CD39 and CD73 are found on the cell surface of lymphocytes and other cell lines. While CD39 produces ADP and AMP via ATP dephosphorylation, CD73 catabolizes AMP to produce adenosine, which inhibits $\mathrm{T}$ lymphocyte response and has an anti-inflammatory effect. The regulatory activity of adenosine starts after it is bound to any of its four receptors: A1, A2A, A2B, and A3. Its effect is greater when bound to receptor A2A. Even though the pathway through which adenosine signals when it is bound to its receptor, in vitro studies have found that CD73 inhibits the proliferation of effector $\mathrm{T}$ lymphocytes in mice; such effects have been proven in $\mathrm{CD} 4{ }^{+}$Treg lymphocytes. Because these markers were later found in human $\mathrm{CD}^{+}$Treg lymphocytes, they are considered therapeutic targets in therapy against cancer [25-27].

Cytotoxic T lymphocyte antigen-4 (CTLA-4, CD152) blocks the production of IL-2, the expression of IL-2R, and the cell cycle of activated T lymphocytes [28]. CTLA-4 antagonizes CD28 and prevents CD28-CD80/CD86 interaction like an inhibition mechanism [29]. Also, when there is CTLA-4 engagement, the membrane-proximal region of the CTLA-4 cytoplasmic domain delivers a tyrosineindependent signal that inhibits $\mathrm{T}$ cell activation, another inhibition mechanism by CTLA-4 [30-32]. Recent works propose a different CTLA-4 suppressor mechanism that involves the capture and depletion of its ligands, CD80 and CD86, from antigen-presenting cells by transendocytosis. During the process, CD80/CD86 are transferred into CTLA-4-expressing cells. Therefore, not only does CTLA-4 uptake its ligands and internalize them but also is likely to degrade them [33-35]. A reduced costimulation in T lymphocytes also reduces positive signals between them and antigen-presenting cells that promote the maturation of the latter. This event occurs in the infiltration of $\mathrm{T}$ cells in some types of cancer $[28,36,37]$. The subpopulations of Treg $\mathrm{CD} 8^{+}$CTLA $-4^{+}$suppress the immune response against tumor, inhibiting the proliferation of effector T lymphocytes, where they can participate in the regulatory mechanism of IL-35 [38] and are also able to inhibit dependent allogeneic responses [39].

For its part, LAG-3 (lymphocyte activation gene 3 ) is a molecule with a similar structure to CD4. Because of this similarity, it competitively binds to MHC-II molecules with higher affinity than CD4. When it binds to MHC-II in antigen-presenting cells, it signals in a negative way, unlike CD4 does [40-42]. Therefore, LAG-3 interacts with the TCR-CD3 complex and inhibits its signaling [43]. The interaction between LAG-3 and MHC-II inhibits the activation and proliferation of $\mathrm{CD} 4^{+}$and $\mathrm{CD} 8^{+} \mathrm{T}$ cells and the production of cytokines from a Th1 subset [44]. This immune system suppression molecule acts against tumors by blocking them with an antibody, restoring the immune response [45]. Finally, its presence in regulatory cells can decrease the severity of autoimmune diseases [46].

FasL is a molecule involved in the induction of apoptosis of a target cell, a mechanism used by $\mathrm{CD}^{+}$Treg lymphocytes to kill effector $\mathrm{T}$ cells in a direct cytotoxicity. For this regulatory mechanism to work, it is essential that the Treg lymphocyte and the target cell express FasL and Fas, respectively $[47,48]$.

The characterization of $\mathrm{CD}^{+}$Treg lymphocytes via the detection of membrane molecules that identify them should be complemented with the research on soluble molecules they express.

1.2. Soluble Molecules. FoxP3 is an intracellular DNAbinding protein that prevents transcription and probably involves the direct repression of NF-AT-mediated transcription $[4,49,50]$. It was initially described in scurfy mice that do not express FoxP3. Studies found that $\mathrm{CD}^{+} \mathrm{T}$ lymphocytes in scurfy mice were chronically activated, expressing high levels of several activation markers and cytokines ex vivo. This lymphocyte hyperactivation phenotype was refractory to inhibition with a number of drugs, specifically immunosuppressants cyclosporine A and rapamycin [51]. The phenotype of these mutant mice is similar to the one observed in CTLA-4-deficient mice, indicating that FoxP3 is an important regulator of $\mathrm{T}$ lymphocyte activation [52]. In $\mathrm{CD} 4^{+}$Treg lymphocytes, FoxP3 
is a suppression marker of cell activation and thus used as identification marker. For $\mathrm{CD}^{+}$Treg lymphocytes, the role of FoxP3 is not so clear since it is only expressed in less than $5 \%$ of $\mathrm{CD}^{+} \mathrm{T}$ lymphocytes [53]. However, populations of $\mathrm{CD}^{+}$Treg cells expressing FoxP3 are important immune-suppressors during chronic or asymptomatic infections caused by suboptimal amounts of the infectious agent [54]. They also play this role during GVHD and skin transplantation [55].

The proinflammatory cytokine IFN- $\gamma$ polarizes Th1 immune cell response and has been observed to play another role in $\mathrm{CD}^{+}$Treg lymphocytes. When producing IFN- $\gamma$, these lymphocytes induce IDO production by dendritic and endothelial cells $[4,56]$. This enzyme is responsible for catabolizing tryptophan amino acid. This amino acid is essential to lymphocyte proliferation after activation; therefore, the presence of IDO leads to a decrease in circulating tryptophan levels, restricting the proliferation of activated effector lymphocytes [57]. The single nucleotide polymorphisms (SNPs) of the IDO enzyme are related to autoimmune diseases such as systemic sclerosis [58].

The anti-inflammatory cytokine IL-10 is considered a characteristic molecule of $\mathrm{CD} 4{ }^{+}$Treg lymphocytes. Besides mediating the anti-inflammatory regulatory action, it is added to cultures in order to induce $\mathrm{CD}^{+}$Treg lymphocytes in vitro. A similar observation has been made in $\mathrm{CD}^{+}$Treg lymphocytes, further proving that IL-10 is an evidence of the regulatory function of these cells [59]. For example, IL-10 produced by $\mathrm{CD}^{+}$Treg lymphocytes inhibits $\mathrm{CD}^{+}$, Th1, and Th2 cell proliferation $[60,61]$. In addition, IL-10 suppresses the cytotoxic activity of cytotoxic $\mathrm{T}$ lymphocytes by the reduction of MHC-I expression in target cells [62].

A Treg-specific cytokine, IL-34, has an immunosuppressive function and is involved in the maturation of immunoregulatory macrophages during immunological tolerance processes as pregnancy and the inhibition of rejection in solid organ transplantation $[63,64]$. The cytokine carries out its regulatory function when it is recognized through the Fms receptor, which it shares with the macrophage colonystimulating factor (M-CSF) [65]. Additionally, IL-34 has been found to be involved in the regulation of several subpopulations of tissue resident macrophages, including Langerhans cells and microglia [66].

Another cytokine, IL-35, inhibits the maturation of dendritic cells and the proliferation of $\mathrm{CD}^{+}$and $\mathrm{CD}^{+}$ $\mathrm{T}$ cells and the Th1 polarization of $\mathrm{CD} 4^{+} \mathrm{T}$ lymphocytes [67]. Specifically, this cytokine is involved in the suppressive role of $\mathrm{CD}^{+}$Treg cells in tumors, synergizing with CTLA-4 and avoiding the potentiation of an antitumor immune response [38].

TGF- $\beta$ (transforming growth factor) is an immunoregulatory cytokine that can be expressed in 3 isoforms: TGF- $\beta 1$, TGF- $\beta 2$, and TGF- $\beta 3$, depending on the tissue and the stage of development. It promotes $\mathrm{CD}^{+}$effector $\mathrm{T}$ lymphocyte apoptosis through SMAD-2 signaling and the upregulation of proapoptotic protein Bim [68]. The TGF- $\beta$-producing CD ${ }^{+}$Tregs are able to suppress autoimmune responses very efficiently $[69,70]$. It is known that TGF- $\beta$ acts on antigen- presenting cells as dendritic cells decreasing the expression of costimulation and MHC-I molecules and effector T lymphocytes by inhibiting their proliferation. This has been a mechanism described in the evasion of the antitumor immune response $[71,72]$.

1.3. Absence of Activation Molecules. As previously stated, $\mathrm{CD}^{+}$Treg lymphocytes are characterized by the presence of molecules used as markers to detect and identify these cells. However, it should also be considered that CD8 ${ }^{+}$Treg lymphocytes lack the expression of certain molecules associated to activation and are present in effector $\mathrm{T}$ cells. In mice and human, marker CD28 is scarcely expressed in the thymus and has a reduced expression in peripheral blood cells with anti-inflammatory cytokine production; therefore, it is considered that some subpopulations of $\mathrm{CD}^{+}$Treg could be $\mathrm{CD} 28^{\text {low }}$ [1]. The absence of CD28 in human T lymphocytes correlates with two biological events: cell senescence $[73,74]$ and extended exposure to antigens [75]. Because of that, there is an increase in $\mathrm{CD} 8^{+} \mathrm{CD} 28^{-} \mathrm{T}$ lymphocyte population during chronic inflammatory processes and in elderly subjects. These cells are produced from $\mathrm{CD} 8^{+} \mathrm{T}$ lymphocytes that have repeated antigen stimulation [76]. This explains the fact that elderly subjects show higher concentrations of these lymphocytes. $\mathrm{CD}^{+} \mathrm{T}$ lymphocytes are also unable to proliferate once they are induced to differentiate into CD28 $8^{-}$cells $[77,78]$. They express regulation molecules that are present in $\mathrm{CD}^{+}$Treg lymphocytes as CD39, CTLA-4, and CD25. In addition, studies have proven that they are able to inhibit effector $\mathrm{CD}^{+}$and $\mathrm{CD}^{+}$effector T lymphocytes. These lymphocytes are considered Treg and able to inhibit a Th1-type response [10, 79-81].

The surface marker CD127 (IL-7 receptor $\alpha$-chain) is also absent from $\mathrm{CD}^{+}$Treg lymphocytes, recovering its levels of expression in effector and memory cells [82-85] but not in FoxP3 ${ }^{+}$and those that are likely to be regulatory [85]. There is evidence that CD127 is absent from $\mathrm{CD}^{+}$Treg lymphocytes. This was proven in vitro when differentiating naïve CD ${ }^{+}$T lymphocyte with TGF- $\beta$ and IL-2 and obtaining lymphocytes with suppressor action express-

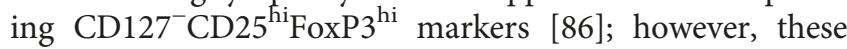
lymphocytes are not so helpful. In humans and mice, $\mathrm{CD}^{+}$and $\mathrm{CD}^{+}$Treg lymphocytes expressing CD25 ${ }^{+-}$ $\mathrm{FoxP}^{+}$exhibit low concentrations or absence of CD127, unlike effector $\mathrm{T}$ cells. This difference is more evident in humans [12].

A $\mathrm{T}$ cell activation marker, CD45RC, is absent or found at low concentrations in $\mathrm{CD}^{+}$Treg lymphocytes involved in solid organ transplant acceptance by IL-34 production [4]. The isoform of CD45, CD45RC, is a transmembrane protein-tyrosine phosphatase that belongs to the Src kinase family. It is essential to signal transduction after $\mathrm{T}$ cell receptor activation and is present in rats, mice, and humans [4, 87-92].

Finally, CD49d is a surface molecule expressed at low levels in $\mathrm{CD}^{+}$Treg lymphocytes. Although the role these lymphocytes play remains unclear, one of their subpopulations can induce apoptosis in activated $\mathrm{T}$ lymphocytes through FasL-Fas interactions [48]. 
TABLE 1: Phenotypes of $\mathrm{CD} 8^{+}$Treg lymphocyte populations and their role in different pathologies.

\begin{tabular}{|c|c|c|c|c|c|}
\hline Pathology & Agent/condition & $\begin{array}{c}\text { Phenotype of } \mathrm{CD}^{+} \text {regulatory } \\
\text { T lymphocytes }\end{array}$ & Exert suppressive action & Model & References \\
\hline \multirow[t]{3}{*}{ Infection } & Mycobacteria & 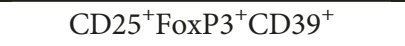 & Inhibit Th1 lymphocyte proliferation & Human & {$[93,94]$} \\
\hline & HIV & $\mathrm{CD} 28^{-} \mathrm{CD} 127^{\mathrm{lo}} \mathrm{CD} 39^{+}$ & Inhibit mononuclear cell proliferation & Human & [97] \\
\hline & Epstein-Barr virus & FoxP $^{+}$ & $\begin{array}{c}\text { Inhibit } \mathrm{CD} 4^{+} \mathrm{T} \text { lymphocyte proliferation } \\
\text { and produce IL-10 }\end{array}$ & Human & {$[98]$} \\
\hline \multirow[t]{6}{*}{$\begin{array}{l}\text { Autoimmune } \\
\text { disease }\end{array}$} & EAE & $\mathrm{CD} 28^{-}$ & $\begin{array}{l}\text { Reduce amount of IFN- } \gamma \text { produced by } \\
\qquad \mathrm{CD} 4^{+} \mathrm{T} \text { lymphocytes }\end{array}$ & Mouse & {$[101]$} \\
\hline & EAE & $\mathrm{CD} 122^{+}$ & $\begin{array}{l}\text { Inhibit characteristic IL-7 production of } \\
\text { inflammatory process during EAE; inhibit } \\
\mathrm{CD}^{+} \mathrm{T} \text { lymphocyte proliferation }\end{array}$ & Mouse & {$[102]$} \\
\hline & Multiple sclerosis & $\mathrm{CD}^{+} \mathrm{CD} 28^{-} \mathrm{CD} 39^{+} \mathrm{CD} 127^{-}$ & Inhibit proliferation & & {$[103,104]$} \\
\hline & SLE & $\mathrm{FoxP}^{+}$ & Regulate by TGF- $\beta$ & Human & [70] \\
\hline & SLE & $\mathrm{CD}_{25^{+}} \mathrm{FoxP}^{+}$ & Suppress production of autoantibodies & Human & [105] \\
\hline & Primary biliary cirrhosis & $\mathrm{CD} 28^{-} \mathrm{CD} 39^{+} \mathrm{CD} 127^{-}$ & Suppress proliferation & Human & {$[106]$} \\
\hline \multirow[t]{3}{*}{ Cancer } & Colorectal cancer & $\mathrm{CD}_{2} 5^{+} \mathrm{FoxP}^{+}$ & $\begin{array}{c}\text { Inhibit } \mathrm{CD} 4^{+} \mathrm{CD} 25^{-} \mathrm{T} \text { lymphocyte and } \\
\text { Th1 cytokine production }\end{array}$ & Human & {$[110]$} \\
\hline & Prostate cancer & $\mathrm{CD}_{2} 5^{+} \mathrm{FoxP} 3^{+}$ & Inhibit naïve $\mathrm{T}$ lymphocyte proliferation & Human & {$[111]$} \\
\hline & $\begin{array}{l}\text { Inoculation with } \\
\text { tumor cell lines }\end{array}$ & CD $39^{+}$Tim $-3^{+} \mathrm{PD}-1^{+} \mathrm{LAG}-3^{+}$ & Exert cytotoxic activity & Mouse & {$[112]$} \\
\hline \multirow[t]{5}{*}{ GVHD } & Allogeneic cells & LAG- $3^{+}$FoxP $3^{+}$CTLA $-4^{+}$ & Suppress allogeneic response via CTLA-4 & Human & {$[39]$} \\
\hline & Allogeneic cells & $\mathrm{CD} 25^{+}$CTLA $-4^{+} \mathrm{FoxP}^{+}$ & $\begin{array}{l}\text { Inhibit cell proliferation and release } \\
\text { of cytokines as IL- } 1 \alpha, \text { IL-17a, IFN- } \gamma \text {, } \\
\text { and TNF- } \alpha\end{array}$ & Human & [115] \\
\hline & Allogeneic cells & $\mathrm{CD} 28^{-}$ & Inhibit $\mathrm{CD} 4^{+} \mathrm{T}$ lymphocyte proliferation & Human & {$[10]$} \\
\hline & Allogeneic cells & $\mathrm{CD}_{25}{ }^{+} \mathrm{FoxP}^{+}$ & Inhibit allogeneic response & Human & [123] \\
\hline & Allogeneic cells & $\mathrm{FoxP}^{+}$ & $\begin{array}{l}\text { Inhibit } \mathrm{CD}^{+} \text {and } \mathrm{CD} 8^{+} \mathrm{T} \text { lymphocyte } \\
\text { proliferation and } \mathrm{CD} 40, \mathrm{CD} 80 \text {, and } \\
\text { CD86 expression in } \mathrm{CD}\end{array}$ & Mouse & {$[125,126]$} \\
\hline
\end{tabular}

GVHD: graft-versus-host disease; HIV: human immunodeficiency virus; EAE: experimental autoimmune encephalomyelitis.

1.4. Participation of $C D 8^{+}$Treg Lymphocytes in Infection, Autoimmunity, Cancer, and GVHD. Membrane, intracellular, and secretory originating molecules from cells previously mentioned have allowed for the characterization and identification of Treg lymphocytes. Additionally, such molecules confer a suppressant activity upon the activation of other cell populations. In literature, $\mathrm{CD} 8^{+}$Treg lymphocytes have been described as key elements in a number of pathologies, including infectious and autoimmune diseases, cancer, and GVHD (Table 1).

1.5. $C D 8^{+}$Treg Lymphocytes in Infectious Diseases. In infectious diseases, $\mathrm{CD}^{+}$Treg lymphocytes reduce immune response against pathogens, which is beneficial to prevent tissue damage caused by an exacerbated response. In contrast, it can also participate in the evasion of host immune response against the pathogen. As an example, the mycobacteria have coexisted with humans for a long time, as M. tuberculosis. These bacteria possess different evasion strategies, like the capacity to induce suppressant activity of the immune response mediated by $\mathrm{CD} 8{ }^{+} \mathrm{CD} 25^{+} \mathrm{FoxP}^{+} \mathrm{CD} 39^{+}$Treg lymphocytes. These lymphocytes, found at higher levels during mycobacteriosis, are able to suppress the proliferation of Th1 (proinflammatory type $1 \mathrm{~T}$ helper cells) that produces
IFN- $\gamma$, necessary to activate other cells against mycobacteria. In addition, the measurement of IFN- $\gamma$ has been used in the diagnosis and monitoring of patients. It has recently been observed that vaccination with bacilli Calmette-Guérin induces an increase in $\mathrm{CD}^{+}$Treg lymphocyte population, which has been related to the low protective action of the vaccine against M. tuberculosis [93, 94] (Figure 2).

In individuals coinfected with hepatitis $\mathrm{C}$ and human immunodeficiency viruses, the TGF- $\beta$ produced by $\mathrm{CD} 8^{+}$ Treg lymphocytes reduces the levels of hepatitis $C$ virusspecific effector $\mathrm{T}$ lymphocytes. This effect is reversed by blocking TGF- $\beta$ and IL-10 produced by Tregs [95]. Additionally, it has been reported that, during HIV infection, the levels of $\mathrm{CD}^{+} \mathrm{CD} 28^{-} \mathrm{CD} 127^{\mathrm{lo}} \mathrm{CD} 39^{+}$Treg lymphocytes are increased with respect to those found in healthy subjects; CD73 is less abundant [96]. The levels are reduced after administering the antiretroviral treatment to the patients. The Tregs observed in HIV patients are antigen-specific and inhibit the proliferation of peripheral-blood lymphocytes. These observations suggest that the suppressant activity of Treg lymphocytes is one of the factors affecting the immune function in HIV patients [97] (Figure 2).

Although the cytomegalovirus can coexist with the human in a subclinical way, it is of great importance in the 


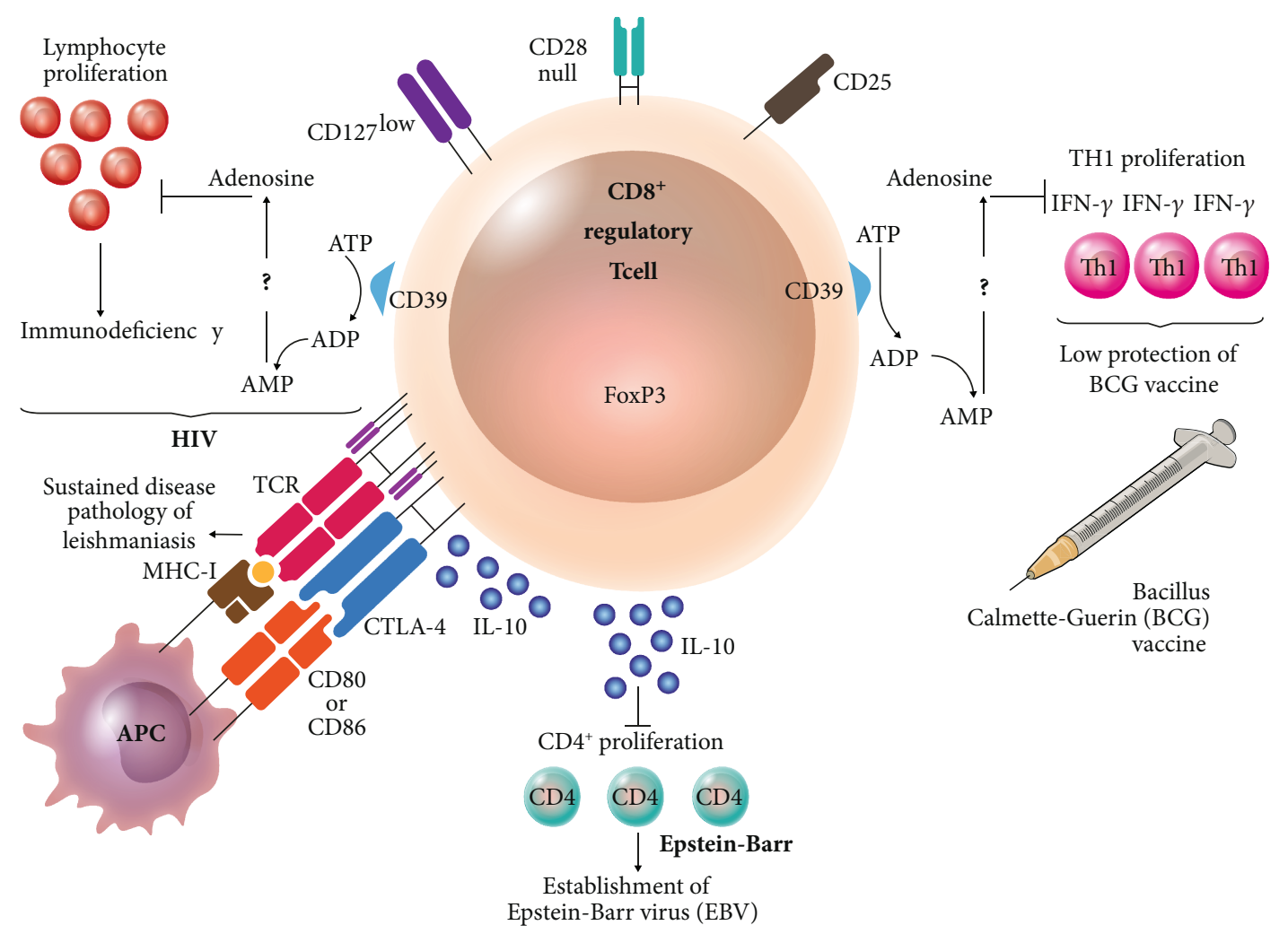

Figure 2: Participation of $\mathrm{CD}^{+}$Treg lymphocytes in infectious diseases. In an infection with human immunodeficiency virus (HIV), CD8 ${ }^{+} \mathrm{T}$ lymphocyte has a phenotype $\mathrm{CD} 28^{-} \mathrm{CD} 127^{\mathrm{lo}} \mathrm{CD} 39^{+}$inhibiting lymphocyte proliferation, which is probably related to the immunodeficiency shown during the disease. In a parasitic infection as leishmaniasis, the persistence of the parasite partly depends on the existence of CD $8^{+}$Treg lymphocytes expressing CTLA-4 and producing IL-10, which results in the prevalence of the disease. During immunosuppression situations, there is an increase in the population of IL-10-producing $\mathrm{CD}^{+} \mathrm{FoxP}^{+}$Treg lymphocytes that inhibit $\mathrm{CD} 4^{+} \mathrm{T}$ cell proliferation, promoting infection by Epstein-Barr virus. The low protection of bacillus Calmette-Guérin vaccine is attributed factors as $\mathrm{CD} 8^{+} \mathrm{CD} 25^{+} \mathrm{CD} 39^{+} \mathrm{Treg}$ lymphocytes that inhibit the proliferation of $\mathrm{CD}^{+} \mathrm{T}$ lymphocytes producing Th1 cytokines as IFN- $\gamma$, necessary to activate other cell lines against mycobacteria.

production of $\mathrm{CD}^{+} \mathrm{T}$ lymphocyte arrays in adult age. This is because studies in adults have found that cytomegalovirus epitope-specific $\mathrm{CD}^{+} \mathrm{T}$ lymphocytes constitute a high percentage (33\%, approximately) of the total CD8 ${ }^{+} \mathrm{T}$ lymphocytes, which might compromise the response against other pathogens [75]. A high ratio of these lymphocytes is probably $\mathrm{CD} 28^{-}$, given that, as it was mentioned before, the absence of CD28 indicates senescence and repeated stimulation with persistent antigens.

Also, $\mathrm{CD}^{+}$Treg lymphocytes are key to the infection process in transplant patients who are under immunosuppressant conditions due to conditioning chemotherapy previous to transplant and subsequent treatment with immunosuppressants to prevent transplant rejection and GVHD. The levels of IL-10-producing CD8 ${ }^{+}$Treg lymphocytes in transplant patients are higher than those in healthy subjects, which agrees and seems to be associated to the presence of opportunistic pathogens as the Epstein-Barr virus, caused by the inhibition of effector $\mathrm{CD} 4^{+} \mathrm{T}$ lymphocyte proliferation [98] (Figure 2).

In parasitic infections, $\mathrm{CD}^{+}$regulatory $\mathrm{T}$ lymphocytes have been found in visceral leishmaniasis patients who express CTLA-4 and produce IL-10 [99] (Figure 2). When dermal sequelae are caused by Leishmania donovani infection, the percentage of $\mathrm{CD} 8^{+} \mathrm{CD} 28^{-} \mathrm{T}$ lymphocytes is increased and only restored after treatment [100].

1.6. $\mathrm{CD}^{+}$Treg Lymphocytes in Autoimmune Diseases. As $\mathrm{CD}^{+}$Tregs, $\mathrm{CD}^{+}$Treg lymphocyte show reduced levels and function in autoimmune disease patients. In mouse experimental autoimmune encephalomyelitis (EAE) studies, it has been observed that $\mathrm{CD} 8^{+} \mathrm{CD} 28^{-}$Treg lymphocytes reduce levels of IFN- $\gamma$ produced by myelin oligodendrocyte glycoprotein-specific $\mathrm{CD}^{+} \mathrm{T}$ lymphocytes. In consequence, the expression of costimulatory molecules in antigen-presenting cells interacting with $\mathrm{CD} 4^{+} \mathrm{T}$ lymphocytes is reduced [101]. In this autoimmunity model, there is also a $\mathrm{CD}^{+} \mathrm{CD} 122^{+}$regulatory $\mathrm{T}$ lymphocyte population. This cell population inhibits IL-17, typical of inflammatory process during EAE, and proliferation of $\mathrm{CD}^{+}{ }^{+} \mathrm{T}$ lymphocytes [102] (Figure 3).

Multiple sclerosis in humans, comparable to EAE in mice, is a disease in which lymphocytes exhibit immune deregulation that is shown as chronic persistent inflammatory response [103]. In that sense, IFN- $\beta$ treatment modulates the immune system, reducing autoreactive $\mathrm{T}$ cell clones and increasing $\mathrm{CD} 8{ }^{+} \mathrm{CD} 25^{+} \mathrm{CD} 28^{-}$Treg lymphocytes together with plasmacytoid dendritic cells. Treatment 


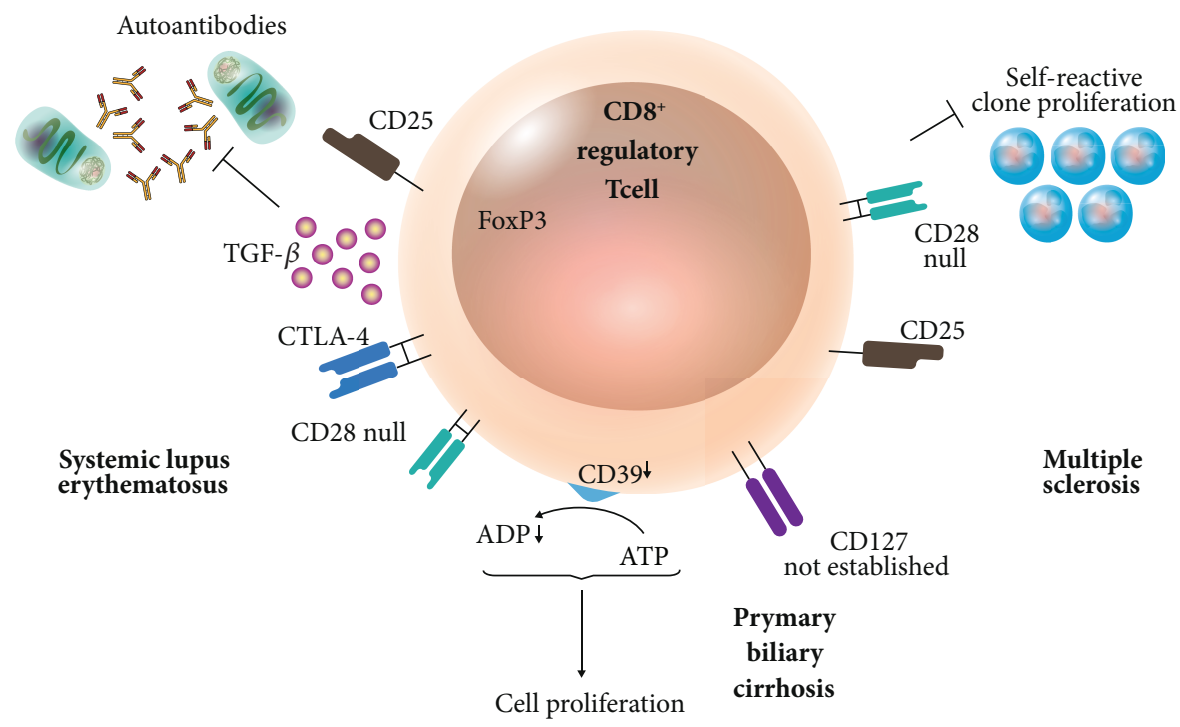

Figure 3: Participation of $\mathrm{CD}^{+}$Treg lymphocytes in autoimmune diseases. During SLE, antibody production is eliminated thanks to the suppressive activity of TGF- $\beta$-producing $\mathrm{CD} 8^{+} \mathrm{CD} 25^{+} \mathrm{FoxP} 3^{+}$Treg lymphocytes, which are induced after an autologous transplant of hematopoietic progenitor cells, achieving the remission of the disease. On the other hand, during primary biliary cirrhosis, $\mathrm{CD} 8^{+} \mathrm{CD} 28^{-} \mathrm{T}$ lymphocytes show decreased CD39 expression and fail to inhibit cell proliferation, promoting the severity of this autoimmune disease. In human multiple sclerosis, therapy with IFN- $\beta$ regulates the immune system by reducing autoreactive $\mathrm{T}$ cell clones and increases $\mathrm{CD} 8{ }^{+} \mathrm{CD} 25^{+} \mathrm{CD} 28^{-}$regulatory T cells. SLE: systemic lupus erythematosus.

with IFN- $\beta$ is highly promising: its use could reduce the activity of the disease [104].

The autologous transplant of hematopoietic progenitor cells in refractory disease systemic lupus erythematosus (SLE) has proven to be highly effective, achieving the remission of the disease. This fact is directly related to the restoration of the $\mathrm{CD} 8^{+} \mathrm{FoxP}^{+}$Treg lymphocyte population characterized by CD103, PD-1, PD-L1, and CTLA-4 expression. In this case, the function of $\mathrm{CD}^{+}$Treg lymphocytes on target cells depends on cell-cell contact and TGF- $\beta$ production by regulatory lymphocytes [70]. In addition, $\mathrm{CD} 8^{+} \mathrm{CD} 25^{+} \mathrm{FoxP}^{+}$regulatory $\mathrm{T}$ lymphocytes have been found to be able of suppressing autoantibody production [105] (Figure 3).

Primary biliary cirrhosis is another autoimmune disease that affects humans. In this disease, $\mathrm{CD} 8^{+}$Treg lymphocytes express low CD39 and high CD127, a condition that does not change even after culturing the lymphocytes with IL-10. Additionally, the lymphocytes show a deficient suppressant function [106] (Figure 3).

1.7. $\mathrm{CD}^{+}$Treg Lymphocytes in Cancer. Immune response has been well documented to be altered in cancer. It has been established that antitumoral immune response is avoided by different types of cancer, including kidney, bladder, and colorectal cancer. Antitumoral evasion has been associated to $\mathrm{CD} 8^{+} \mathrm{CD} 28^{-} \mathrm{CD} 127^{10} \mathrm{CD} 39^{+}$lymphocytes [107] (Figure 4). Such lymphocytes can be produced in tumor tissue thanks to the cytokines produced by tumor cells as GCS-F and IL-10. Furthermore, regulatory lymphocytes can be attracted to the tumor because it releases chemokines as CCL2 and CCL22, highly attractive to regulatory lymphocytes expressing specific CCR2 and CCR4. Also, $\mathrm{CD} 8^{+} \mathrm{CD} 28^{-}$
Treg lymphocytes directly correlate with tumor diagnosis: the higher the concentration of lymphocytes, the worse the diagnosis and vice versa [108]. $\mathrm{CD} 8^{+} \mathrm{CD} 28^{-} \mathrm{T}$ lymphocytes are found at higher levels in advanced stages of non-smallcell lung cancer, maintaining the increase up to the resection of the tumor when there is a decrease in the concentration and the prognosis for the patient is favorable. However, these lymphocytes have yet to be functionally evaluated to confirm whether they were regulatory [109]. In colorectal cancer patients, studies have successfully isolated $\mathrm{CD} 8^{+-}$ $\mathrm{CD} 25^{+} \mathrm{FoxP}^{+}$Treg lymphocytes directly from a tumor. The immunosuppressant phenotype of those lymphocytes is characterized by CTLA- 4 expression and TGF- $\beta$ production. They inhibit $\mathrm{CD} 4^{+} \mathrm{CD} 25^{-} \mathrm{T}$ lymphocyte proliferation ex vivo and suppress Th1 cytokine production in themselves [110]. Therefore, these Treg lymphocytes contribute to immune response evasion against tumor and progression of the disease in consequence. In prostate cancer patients, studies have found tumor-infiltrating regulatory lymphocytes with the same phenotype $\left(\mathrm{CD} 8^{+} \mathrm{CD} 25^{+} \mathrm{FoxP}^{+}\right)$as the one observed in lymphocytes of colorectal cancer patients. These cells are able to inhibit naïve $\mathrm{T}$ lymphocyte proliferation. However, the regulatory activity of these lymphocytes can be reverted by exposing them to TLR-8 ligands as poly-G2. Therefore, the possibility that the manipulation of the TLR8 signaling pathway can revert immunosuppression mediated by Treg lymphocytes and use it as a therapeutic strategy against cancer is promising [111] (Figure 4). In mice, CD8 ${ }^{+}$ Treg lymphocytes have been found as well in cancer induced by inoculation with tumor cell lines. Furthermore, the population $\mathrm{CD} 8^{+} \mathrm{CD} 39^{+} \mathrm{Tim}-3^{+} \mathrm{PD}-1^{+} \mathrm{LAG}-3^{+}$has been found to be tumor-infiltrating, produces low levels of IL2 and TNF, and has a high cytotoxic potential evaluated 


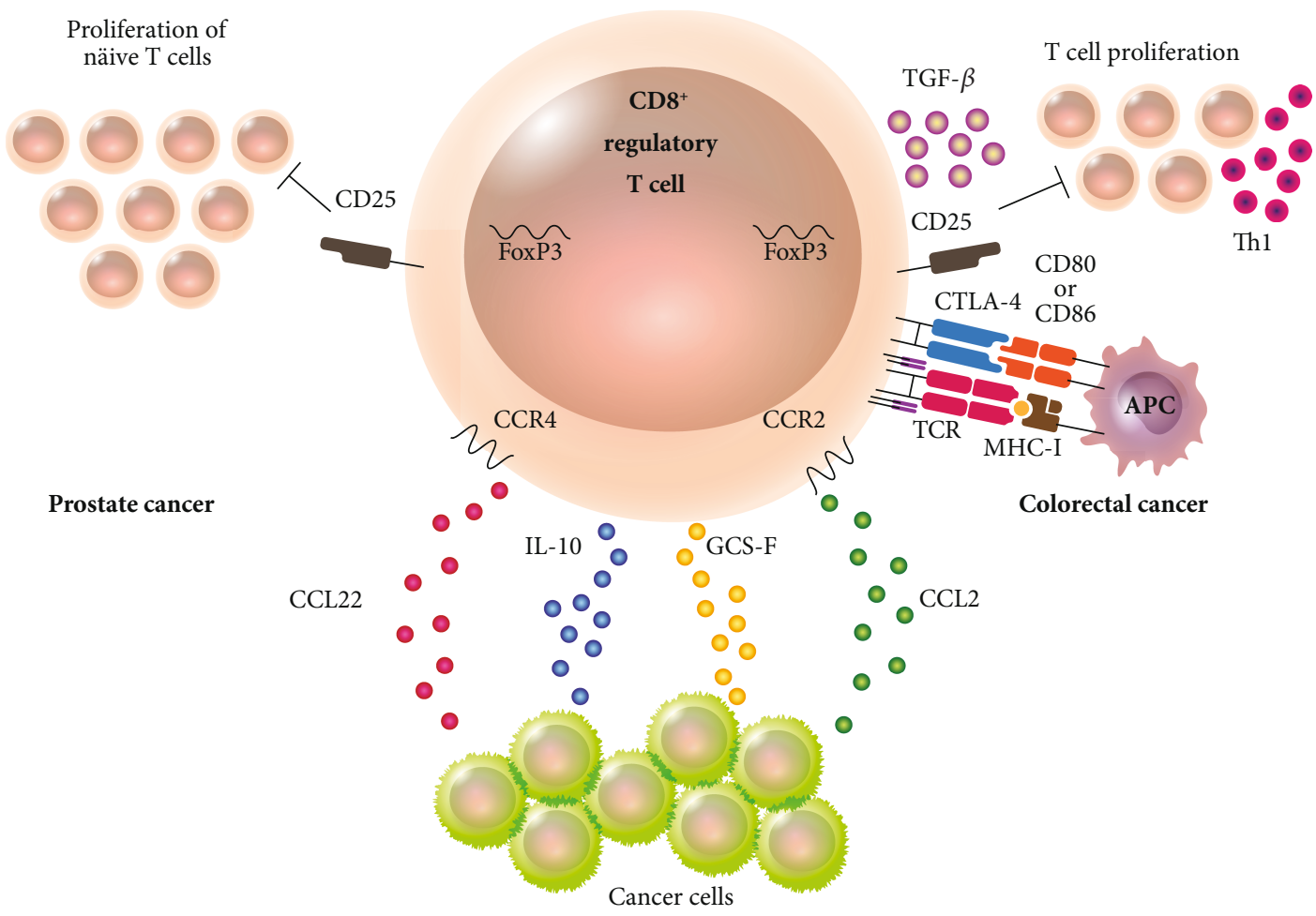

Figure 4: Participation of CD8 ${ }^{+}$Treg lymphocytes in cancer. Regulatory T lymphocytes often aid in the evasion of the immune system by the cancer cell. Specifically, CD8 ${ }^{+}$Tregs can be induced in tumor tissue due to the presence of cytokines as GCS-F and IL-10. They can also be attracted to the tumor after the latter releases the chemokines CCL2 and CCL22 that attract regulatory lymphocytes expressing CCR2 and CCR4. In colorectal cancer, $\mathrm{CD} 8^{+} \mathrm{CD} 25^{+} \mathrm{FoxP} 3^{+}$Treg lymphocytes with an immunosuppressive phenotype characterized by expressing CTLA- 4 and TGF- $\beta$ inhibit Th1 lymphocyte proliferation. In prostate cancer, $\mathrm{CD} 8^{+} \mathrm{CD} 25^{+} \mathrm{FoxP} 3^{+}$Treg lymphocytes have been found to share markers with colorectal cancer and can inhibit naïve $\mathrm{T}$ lymphocyte proliferation.

by granzyme B activity and CD107a mobilization. The expression of CD39 in Treg lymphocytes is created by a recognition of the TCR pathway and promoted by IL-6 and IL27 , which are present in the microenvironment surrounding the tumor. The manipulation of the microenvironment, as well as some therapeutic strategy whose target molecule is CD39, might reduce the evasion of the immune system promoted by Treg lymphocytes and improve the immune response against cancer [112].

1.8. $\mathrm{CD}^{+}$Treg Lymphocytes in Graft-versus-Host Disease. $\mathrm{CD}^{+}$Treg lymphocytes have been described in solid organ transplant and bone marrow transplant as well, which is currently used as hematopoietic stem cell transplantation. In solid organ transplantation, $\mathrm{CD}^{+}$Treg lymphocytes reduce the risk of transplant rejection in the host by creating host tolerance towards the received tissue or organ $[47,113]$. An inverse situation occurs in hematopoietic stem cell transplantation: $\mathrm{CD}^{+}$Treg lymphocytes participate in the tolerance of donor cells towards the host's tissues. In addition to undergoing ablation of their bone marrow, the host is immunosuppressed by the pharmacological treatment received prior to the transplant and is therefore susceptible to attacks by the immune system cells of the donor. In this situation, the available Treg lymphocytes reduce the risk of GVHD, decreasing the intensity of the damage caused by the donor's cells (Figure 5). As a beneficial collateral effect on the host, a graft-versus-tumor can occur mediated by donor cell, lowering the risk of primary disease relapse. The immunosuppressant effect of Treg cells that prevent GVHD apparently does not compromise the effect of graft-versustumor $[114,115]$. Still, $\mathrm{CD}^{+}$Treg lymphocytes are not always found in sufficient quantities, which seems to predispose the patient to GVHD.

Because the inherent immune response to the disease is proinflammatory, the pharmacotherapy given to patients against the illness includes strong immunosuppressants that jeopardize the patient's health since they can lead to infections and/or primary disease relapse. Although the immune response of effector T lymphocytes in the graft versus leukemic cells of the host is needed to prevent relapse, an exacerbated immune response, along with a reduced number of Treg lymphocytes, might cause the death of the host by triggering severe GVHD [116].

This disease causes severe damage in a number of organs, including tissues such as skin, liver, and gastrointestinal tract. It is triggered when immunocompetent donor cells recognize the host cells as foreign and its onset depends on three factors: (1) infused donor cells must be immunocompetent; (2) the host must have antigens absent in the graft; and (3) the host must be unable to generate a response against the graft [117].

Then, why is GVHD generated? It is well known that the main reason of graft rejection in solid organ transplant 


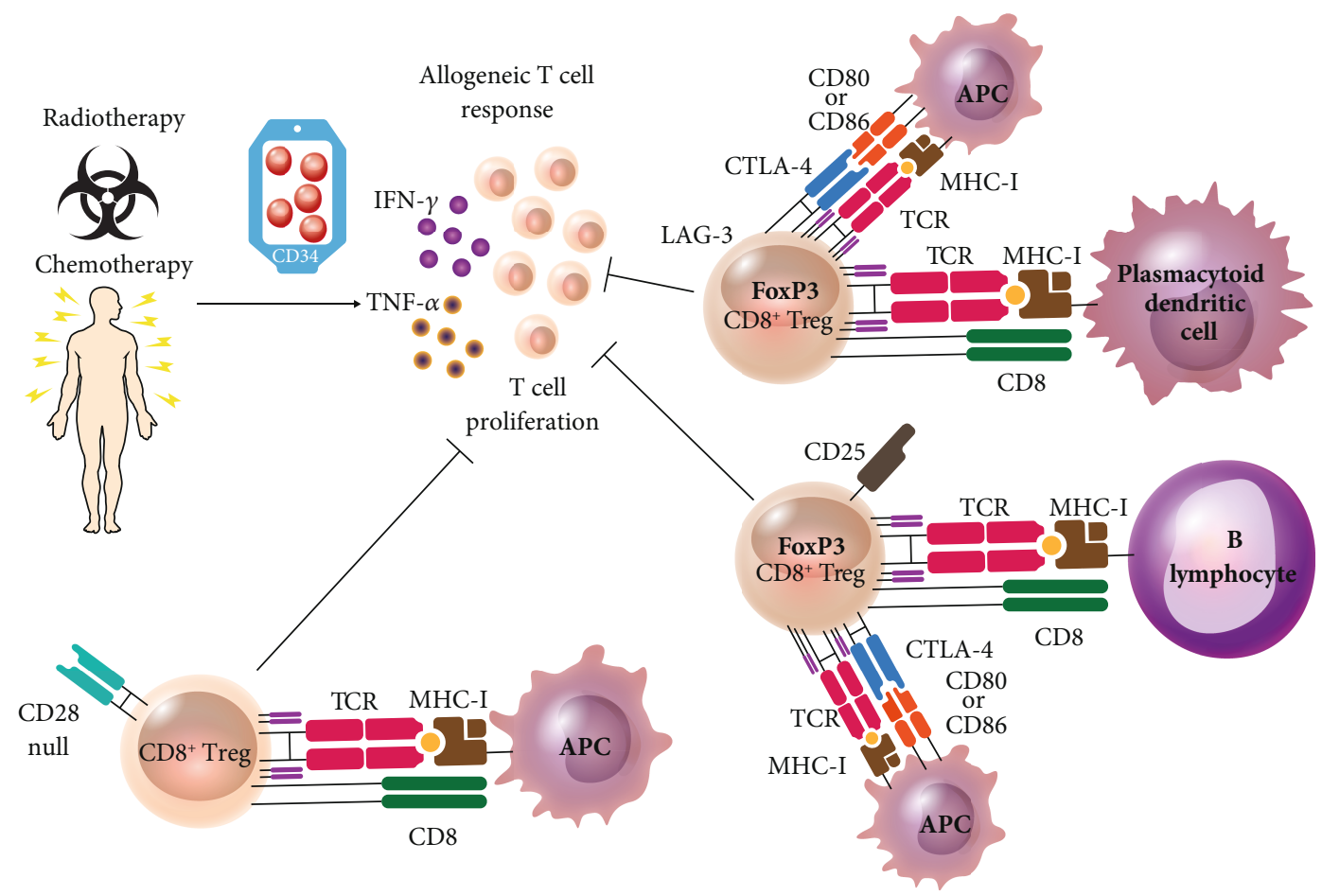

Figure 5: Participation of CD8 ${ }^{+}$Treg lymphocytes in GVHD. After the remission of an oncohematologic disease, patients are treated with chemotherapy and radiotherapy. Later, they receive a hematopoietic stem cell graft from an HLA-compatible donor, at risk of developing GVHD that is characterized by being proinflammatory and producing IFN- $\gamma$ and TNF- $\alpha$. This response can be stopped by CD $8^{+}$Treg lymphocytes. When they encounter a plasmacytoid dendritic cell, lymphocytes are activated; they acquire phenotype LAG$3^{+} \mathrm{FoxP}^{+} \mathrm{CTLA}-4^{+}$and are able to suppress $\mathrm{T}$ lymphocyte allogeneic response via CTLA- 4 . If they are activated by a B lymphocyte, the $\mathrm{CD}^{+}$Tregs will express $\mathrm{CD} 25^{+} \mathrm{CTLA}-4^{+} \mathrm{FoxP}^{+}$, which suppresses cell proliferation and release of proinflammatory cytokines. The $\mathrm{CD} 8^{+} \mathrm{CD} 28^{-}$, a regulatory $\mathrm{T}$ cell subpopulation, play a critical role in in vitro and in posttransplantation allogeneic response. They can be generated by in vitro interaction with allogeneic peripheral blood mononuclear cells. Epitope presented in MHC-I is an alopeptide (allogeneic peptide) in all three Treg phenotypes.

patients (as in kidney transplant) is high incompatibility between donor and host in HLA histocompatibility. Despite HLA compatibility between donor and host for HLA cells expressing high polymorphism is sought in hematopoietic stem cell transplantation, there may be differences in the HLA showing lower polymorphism that they are not studied routinely. Therefore, foreign antigen recognition after transplant by donor cells is latent and can trigger GVHD [118]. In addition to these risk factors, we must also consider nonHLA genes. An example is that some polymorphisms have been identified in regulatory sequences of genes associated to NK cell KIR receptors. Ligands of KIR receptors are class I HLA molecules. In consequence, the absence of the correct ligands for KIR receptors during hematopoietic stem cell transplanting can lead to cytotoxic activity of the donor NK cells. This can be beneficial to the patient because primary disease relapse is avoided; however, the severity of GVHD is increased as well [119]. Simultaneously, other factors have been related to the development of the disease. Some of them are the source of hematopoietic stem cells (the risk of GVHD is higher when peripheral blood mobilized with growth factors to induce the exit of stem cells is transfused than when bone marrow is transfused), the patient's age (higher risk is associated to older ages), and conditioning of the host with chemotherapy and/or radiotherapy and prophylaxis [117].
These risk factors place GVHD as one of the main causes of failure in hematopoietic stem cell allogeneic transplantation. Nearly $60 \%$ of the transplant patients at the Centro Médico Nacional "La Raza" of the Instituto Mexicano del Seguro Social in Mexico City suffer GVHD (unpublished data).

Some hypotheses consider $\mathrm{CD}^{+}$Treg lymphocytes as responsible for tolerance in the first days after hematopoietic stem cell transplant. This is because, after the transplant, the first $\mathrm{T}$ lymphocytes to be present in the peripheral blood are $\mathrm{CD}^{+}$, followed by $\mathrm{CD} 4^{+}$lymphocytes in a later stage [120]. Furthermore, recent studies show that when higher concentrations of $\mathrm{CD}^{+} \mathrm{T}$ lymphocytes are found in the graft, the possibility of primary disease relapse is reduced without increasing the risk of GVHD. Still, these lymphocytes were not characterized beyond the expression of molecule CD8 on their surface [121].

In GVHD, $\mathrm{CD}^{+}$Treg lymphocytes have been identified as antigen-specific that are activated when they encounter foreign antigens; that is, they are alloreactive. Their activation is triggered by the encounter of an antigen-presenting cell, like a dendritic cell or a B lymphocyte. In humans, lymphocytes are activated when they encounter a plasmacytoid dendritic cell and acquire a LAG $-3^{+} \mathrm{FoxP} 3^{+} \mathrm{CTLA}-4^{+}$phenotype. These cells are able to suppress the allogeneic response of $\mathrm{T}$ lymphocytes via CTLA-4 [39]. If the activating cell is a B 
lymphocyte, the phenotype acquired by the $\mathrm{CD} 8^{+}$Treg lymphocyte will be $\mathrm{CD} 25^{+} \mathrm{CTLA}-4^{+} \mathrm{FoxP}^{+}$. This phenotype suppresses cell proliferation and release of proinflammatory cytokines as IL- $1 \beta$, IL-2, IL-17a, IFN- $\gamma$, and TNF- $\alpha$ by autologous peripheral blood mononuclear cells; CTLA- 4 is the molecule with the most involvement in this suppressant function [115] (Figure 5). During the follow-up after a year, a different population of $\mathrm{CD} 8^{+} \mathrm{CD} 28^{-}$Treg lymphocytes was observed to be increased and constant in vivo in patients that were infused with allogeneic donor cells, using B7-blocking reagents like CTLA-4-Ig that inhibit CD28-B7 together with CTLA-4-B7 interactions as immunosuppressive agent. All the patients survived without showing GVHD [10]. After an allogeneic hematopoietic stem cell transplant, $\mathrm{CD} 8{ }^{+} \mathrm{CD} 28$ - $\mathrm{T}$ lymphocytes are found in increased percentage in the patient (Figure 5). These lymphocytes are antigen-specific for tumors related to leukemia patients in remission. Additionally, their proliferation and degranulation are stopped and they become senescent with short telomeres [122].

In human in vitro experiments in which the allogeneic condition occurring in a transplant was simulated, $\mathrm{CD} 8^{+-}$ $\mathrm{CD} 25^{-} \mathrm{T}$ lymphocytes of a donor were incubated together with dendritic cells of a different donor. This culture yielded $\mathrm{CD}^{+} \mathrm{CD} 25^{+} \mathrm{FoxP}^{+}{ }^{+}$Treg lymphocytes that were able to inhibit the allogeneic immune response without affecting the one against the cytomegalovirus, a risk of infection among patients transplanted with hematopoietic stem cells [123]. Another study found that the $\mathrm{CD}^{+}$cells found in higher concentrations in patients without GVHD expressed FoxP $^{+}$, unlike GVHD patients. The latter exhibited higher levels of IFN- $\gamma$-producing Tc1 and IL-17-producing Tc17 lymphocytes [124].

In mice, $\mathrm{CD}^{+} \mathrm{FoxP}^{+}$lymphocytes are the most relevant population and are sufficient to decrease the severity of GVHD [125, 126]. These mouse lymphocytes express the transcription factor FoxP3 and GITR, CD62L, CD28, and CTLA-4 molecules. They produce lower levels of IL-10 and IL-17 and higher concentrations of IFN- $\gamma$. Additionally, they inhibit $\mathrm{CD}^{+}$and $\mathrm{CD}^{+} \mathrm{T}$ lymphocyte proliferation and expression of costimulatory CD40, CD80, and CD86 molecules during antigenic presentation by dendritic cells [126].

Although the direction of the immune response during graft rejection is inverse to the one present during GVHD, it is also caused by an exacerbated immune response. According to evidence, this response can be controlled by $\mathrm{CD}^{+}$Treg lymphocytes. In that regard, different subpopulations of $\mathrm{CD}^{+}$Treg lymphocytes have been described in solid organ transplantation. For instance, the human kidney is not rejected when the percentage of $\mathrm{CD} 8^{+} \mathrm{CD} 28^{-}$and $\mathrm{CD} 4^{+-}$ $\mathrm{CD} 25^{+} \mathrm{FoxP}^{+}{ }^{+}$Treg lymphocytes increases during the first six months after the transplant [127].

On the other hand, $\mathrm{CD} 8^{+} \mathrm{CD} 122^{+} \mathrm{PD}-1^{+}$Treg lymphocytes reduced rejection to skin graft in mice. These lymphocytes exert a regulatory activity independently from FasL-Fas and thus promote effector $\mathrm{CD}^{+} \mathrm{T}$ lymphocyte apoptosis. The inhibition of effector T lymphocyte proliferation depended on IL-10 [47].
A $\mathrm{CD}^{+}$Treg lymphocyte subpopulation recently described in rats is specific for at least two allogeneic class II MHC peptides in a heart transplant model [128]. This subpopulation shows a low expression or absence of CD45RC $\left(\mathrm{CD} 45 \mathrm{RC}^{\mathrm{lo} /-}\right)[63,128]$. These lymphocytes exert a regulatory action through IL-34 that they produce. This cytokine acts generating regulatory macrophages from monocytes, promoting in turn the suppressor activity of $\mathrm{CD}^{+-}$ CD45RC ${ }^{\text {low }} \mathrm{T}$ lymphocytes. Apparently, $\mathrm{CD} 8^{+} \mathrm{CD} 45 \mathrm{RC}^{\mathrm{lo} /-}$ lymphocytes have a regulatory activity only when they are the result of blocking the interaction CD40-CD40L $\left(\mathrm{CD} 8^{+} \mathrm{CD} 40 \mathrm{lg}\right)$ since they produce more IL-34 than naive $\mathrm{CD} 8^{+} \mathrm{CD} 45 \mathrm{RC}^{\mathrm{lo} /-}$ lymphocytes (spleen), which are positive to FoxP3. Their regulatory activity can be proven by their ability to inhibit effector $\mathrm{CD} 4^{+} \mathrm{CD} 25^{-} \mathrm{T}$ lymphocyte proliferation, which was induced by IL-34 in a dose-dependent manner. When in vivo, these lymphocytes extended the acceptance of the allograft while the production of antibodies against the graft was inhibited [63]. This might constitute a therapeutic strategy to reduce the fatality of acute GVHD in humans, as proven by the use of human anti-CD45RC antibodies in humanized mice [129].

Those $\mathrm{CD}^{+}$Treg lymphocyte populations that mediate solid organ transplant rejection in GVHD are likely to play a key role in decreasing acuteness of GVHD and promoting the graft-versus-tumor effect.

1.9. Concluding Remarks. Although $\mathrm{CD} 8^{+}$lymphocytes are described to have an immunosuppressive action, $\mathrm{CD}^{+}$ lymphocytes have been more thoroughly characterized, becoming the model to describe $\mathrm{CD}^{+}$Treg lymphocytes. No exclusive markers have been described for any of these regulatory lymphocyte populations. For this reason, more than one criterion has been employed to characterize and identify them. The three requisites that must be met to identify $\mathrm{CD}^{+}$Treg lymphocytes are as follows: (1) they must express more than one marker indicating regulation. (2) They must produce anti-inflammatory cytokines as IL-10 and/or TGF- $\beta$, and (3) they must inhibit the proliferation of $\mathrm{CD}^{+}$and/or $\mathrm{CD}^{+}$effector $\mathrm{T}$ lymphocytes. Although FoxP3 is a less abundant marker for $\mathrm{CD}^{+}$Treg lymphocytes when compared against $\mathrm{CD} 4^{+} \mathrm{Treg}$, it is relevant to $\mathrm{CD} 8^{+}$Treg identification.

The markers that have been described are useful to group Treg lymphocytes in different subpopulations according to their characteristics, location, or role in a pathology. In order to be certain of a subpopulation taking part in GVHD regulation, studies should choose the population with the highest number of markers. This would improve the specificity, but populations showing all the markers would be very small. Working with a reduced and insufficient quantity of $\mathrm{CD} 8^{+}$ Treg lymphocytes would be inconvenient. If the aim is to find an abundant and regulatory population, it would probably be best to look for subpopulation $\mathrm{CD} 8^{+} \mathrm{CD} 28^{-}$ and check its regulatory activity, seeking anti-inflammatory cytokine production and proliferation inhibition. A thorough characterization is important given that a $\mathrm{CD} 8^{+} \mathrm{CD} 28^{-} \mathrm{T}$ lymphocyte population might also contain effector lymphocytes $[130,131]$. In general, if we were to look for $\mathrm{CD}^{+}$Treg 
lymphocytes specific of a pathology, we would resort to the information provided, as shown in Table 1.

The benefits of $\mathrm{CD} 8^{+}$Treg lymphocyte participation vary between the pathologies in which the cells play a role. In infectious diseases, it is desirable for the lymphocytes to counter the exacerbated inflammation produces as a response to the microorganism to prevent damage in own tissue. However, an increased participation of regulatory cells might contribute to the pathogen's evasion of the immune response generated by the host and the consequent persistence of the parasite. As shown in Figure 2, $\mathrm{CD}^{+}$Treg lymphocytes that express ectoenzyme CD39 produce adenosine, which suppresses immune response against two agents: one viral and one bacterial. On the other hand, $\mathrm{CD}^{+}$Treg lymphocytes allow for the establishment of a parasitic and a viral agent, through IL-10.

Although they are present in some autoimmune diseases and show a presumptive regulatory phenotype, lymphocytes express their regulatory molecules at low levels. In consequence, the molecules are not effective to inhibit lymphocytes and innate immune response cells, responsible for triggered autoimmune inflammatory response. However, effector $\mathrm{CD}^{+}$Treg lymphocytes inhibiting autoantibody production have been identified in systemic lupus erythematosus (Figure 3).

In cancer progression, $\mathrm{CD} 8^{+}$Treg lymphocytes exhibit higher levels and seem to be a tumor-mediated immunosuppressive strategy. They are attracted to the tumor and their permanence is promoted thanks to the evasion of the immune response that might eradicate cancer cells (Figure 4).

Finally, two events occur after an allogeneic hematopoietic stem cell transplant. The first one is GVHD, which can be exhibited in four stages, according to its severity (being 4 the most severe stage). On the other hand, there is the desired graft-versus-tumor effect, in which a strong participation of $\mathrm{CD}^{+}$Treg lymphocytes is not convenient since it would allow for the reestablishment of the primary disease.

Some in vitro studies have obtained $\mathrm{CD} 8{ }^{+} \mathrm{CD} 28^{-}$Treg lymphocytes by stimulation of the microenvironment of the cells after an allogeneic transplant, inducing alloanergized $\mathrm{CD} 8^{+}$Treg cells. Furthermore, these same markers have been found in increased lymphocyte populations of transplant patients induced to tolerance with belatacept, an immunosuppressant from a fusion molecule bound to CTLA-4. These data define this as one of the ideal cell populations to be studied in allogeneic hematopoietic stem cell transplantation [10]. However, this is not the only $\mathrm{CD}^{+}$Treg lymphocyte subpopulation involved in the modulation of the immune response in GVHD. Those $\mathrm{CD} 8^{+}$Treg lymphocytes with CTLA-4-mediated suppressor activity that are induced by B lymphocytes and plasmacytoid dendritic cells are effective against an allogeneic response (Figure 5).

The study of $\mathrm{CD}^{+}$Treg cells is not yet complete. A detailed analysis of their identification, regulation mechanisms, and ways of induction, among other events, will allow researchers to know the proportion of $\mathrm{CD} 8^{+}$Treg and $\mathrm{CD} 4^{+}$ effector lymphocytes. This will allow for a cell therapy to prevent and cure infectious and autoimmune diseases as well as cancer and GVHD.

\section{Conflicts of Interest}

The authors declare that there is no conflict of interest regarding the publication of this paper.

\section{References}

[1] Y. Vuddamalay, M. Attia, R. Vicente et al., "Mouse and human $\mathrm{CD}^{+} \mathrm{CD} 28^{\text {low }}$ regulatory $\mathrm{T}$ lymphocytes differentiate in the thymus," Immunology, vol. 148, no. 2, pp. 187196, 2016.

[2] R. K. Gershon and K. Kondo, "Cell interactions in the induction of tolerance: the role of thymic lymphocytes," Immunology, vol. 18, no. 5, pp. 723-737, 1970.

[3] R. K. Gershon, E. M. Lance, and K. Kondo, "Immuno-regulatory role of spleen localizing thymocytes," Journal of Immunology, vol. 112, no. 2, pp. 546-554, 1974.

[4] C. Guillonneau, M. Hill, F. X. Hubert et al., "CD40Ig treatment results in allograft acceptance mediated by $\mathrm{CD}^{+-}$ CD45RC ${ }^{\text {low }} \mathrm{T}$ cells, IFN- $\gamma$, and indoleamine 2,3-dioxygenase," The Journal of Clinical Investigation, vol. 117, no. 4, pp. 1096-1106, 2007.

[5] D. Sun, Y. Qin, J. Chluba, J. T. Epplen, and H. Wekerle, "Suppression of experimentally induced autoimmune encephalomyelitis by cytolytic T-T cell interactions," Nature, vol. 332, no. 6167, pp. 843-845, 1988.

[6] J. Zhang, R. Medaer, P. Stinissen, D. Hafler, and J. Raus, "MHC-restricted depletion of human myelin basic proteinreactive $\mathrm{T}$ cells by $\mathrm{T}$ cell vaccination," Science, vol. 261, no. 5127, pp. 1451-1454, 1993.

[7] H. C. Probst, K. McCoy, T. Okazaki, T. Honjo, and M. van den Broek, "Resting dendritic cells induce peripheral CD8 T cell tolerance through PD-1 and CTLA-4," Nature Immunology, vol. 6, no. 3, pp. 280-286, 2005.

[8] A. T. Endharti, M. Rifa', Z. Shi et al., "Cutting Edge: CD8 ${ }^{+-}$ $\mathrm{CD} 122^{+}$regulatory $\mathrm{T}$ cells produce IL- 10 to suppress IFN- $\gamma$ production and proliferation of $\mathrm{CD} 8^{+} \mathrm{T}$ cells," The Journal of Immunology, vol. 175, no. 11, pp. 7093-7097, 2005.

[9] P. Poussier, T. Ning, D. Banerjee, and M. Julius, "A unique subset of self-specific intraintestinal $t$ cells maintains gut integrity," The Journal of Experimental Medicine, vol. 195, no. 11, pp. 1491-1497, 2002.

[10] C. M. Barbon, J. K. Davies, A. Voskertchian et al., "Alloanergization of human $\mathrm{T}$ cells results in expansion of alloantigenspecific $\mathrm{CD} 8^{+} \mathrm{CD} 28^{-}$suppressor cells," American Journal of Transplantation, vol. 14, no. 2, pp. 305-318, 2014.

[11] V. Pillai, S. B. Ortega, C. K. Wang, and N. J. Karandikar, "Transient regulatory T-cells: a state attained by all activated human T-cells," Clinical Immunology, vol. 123, no. 1, pp. 1829, 2007.

[12] G. Churlaud, F. Pitoiset, F. Jebbawi et al., "Human and mouse $\mathrm{CD}^{+} \mathrm{CD} 25^{+} \mathrm{FOXP}^{+}$regulatory $\mathrm{T}$ cells at steady state and during interleukin-2 therapy," Frontiers in Immunology, vol. 6, p. 171, 2015.

[13] X. Zhang, S. Sun, I. Hwang, D. F. Tough, and J. Sprent, "Potent and selective stimulation of memory-phenotype $\mathrm{CD}^{+} \mathrm{T}$ cells in vivo by IL-15," Immunity, vol. 8 , no. 5, pp. 591-599, 1998. 
[14] A. D. Judge, X. Zhang, H. Fujii, C. D. Surh, and J. Sprent, "Interleukin 15 controls both proliferation and survival of a subset of memory-phenotype $\mathrm{CD} 8^{+} \mathrm{T}$ cells," The Journal of Experimental Medicine, vol. 196, no. 7, pp. 935-946, 2002.

[15] H. Dai, N. Wan, S. Zhang, Y. Moore, F. Wan, and Z. Dai, "Cutting edge: programmed death-1 defines $\mathrm{CD} 8{ }^{+} \mathrm{CD} 122^{+}$ $\mathrm{T}$ cells as regulatory versus memory T cells," Journal of Immunology, vol. 185, no. 2, pp. 803-807, 2010.

[16] Y. Okuno, A. Murakoshi, M. Negita, K. Akane, S. Kojima, and $\mathrm{H}$. Suzuki, "CD8 ${ }^{+} \mathrm{CD} 122^{+}$regulatory $\mathrm{T}$ cells contain clonally expanded cells with identical CDR3 sequences of the T-cell receptor $\beta$-chain," Immunology, vol. 139, no. 3, pp. 309-317, 2013.

[17] M. Rifa'i, Y. Kawamoto, I. Nakashima, and H. Suzuki, "Essential roles of $\mathrm{CD} 8{ }^{+} \mathrm{CD} 122^{+}$regulatory $\mathrm{T}$ cells in the maintenance of T cell homeostasis," The Journal of Experimental Medicine, vol. 200, no. 9, pp. 1123-1134, 2004.

[18] Z. Dai, S. Zhang, Q. Xie et al., "Natural CD8 ${ }^{+} \mathrm{CD} 122^{+} \mathrm{T}$ cells are more potent in suppression of allograft rejection than $\mathrm{CD} 4{ }^{+} \mathrm{CD} 25^{+}$regulatory T cells," American Journal of Transplantation, vol. 14, no. 1, pp. 39-48, 2014.

[19] L.-X. Wang, Y. Li, G. Yang et al., "CD122 ${ }^{+} \mathrm{CD} 8^{+}$Treg suppress vaccine-induced antitumor immune responses in lymphodepleted mice," European Journal of Immunology, vol. 40, no. 5, pp. 1375-1385, 2010.

[20] F. Qiu, H. Liu, C. L. Liang, G. D. Nie, and Z. Dai, “A new immunosuppressive molecule emodin induces both $\mathrm{CD} 4^{+-}$ $\mathrm{FoxP}^{+}$and $\mathrm{CD} 8^{+} \mathrm{CD} 122^{+}$regulatory $\mathrm{T}$ cells and suppresses murine allograft rejection," Frontiers in Immunology, vol. 8, p. 1519, 2017.

[21] Z. Shi, Y. Okuno, M. Rifa'i et al., "Human $\mathrm{CD} 8^{+} \mathrm{CXCR}^{+} \mathrm{T}$ cells have the same function as murine $\mathrm{CD} 8^{+} \mathrm{CD} 122^{+}$Treg," European Journal of Immunology, vol. 39, no. 8, pp. 21062119, 2009.

[22] K. L. Cepek, S. K. Shaw, C. M. Parker et al., "Adhesion between epithelial cells and T lymphocytes mediated by Ecadherin and the $\alpha^{\mathrm{E}} \beta_{7}$ integrin," Nature, vol. 372, no. 6502, pp. 190-193, 1994.

[23] K. Franciszkiewicz, A. Le Floc'h, M. Boutet, I. Vergnon, A. Schmitt, and F. Mami-Chouaib, "CD103 or LFA-1 engagement at the immune synapse between cytotoxic $\mathrm{T}$ cells and tumor cells promotes maturation and regulates T-cell effector functions," Cancer Research, vol. 73, no. 2, pp. 617-628, 2013.

[24] A. Le Floc'h, A. Jalil, I. Vergnon et al., “ $\alpha_{\mathrm{E}} \beta_{7}$ integrin interaction with E-cadherin promotes antitumor CTL activity by triggering lytic granule polarization and exocytosis," The Journal of Experimental Medicine, vol. 204, no. 3, pp. 559570, 2007.

[25] J. Bastid, A. Regairaz, N. Bonnefoy et al., "Inhibition of CD39 enzymatic function at the surface of tumor cells alleviates their immunosuppressive activity," Cancer Immunology Research, vol. 3, no. 3, pp. 254-265, 2015.

[26] S. Deaglio, K. M. Dwyer, W. Gao et al., "Adenosine generation catalyzed by CD39 and CD73 expressed on regulatory T cells mediates immune suppression," The Journal of Experimental Medicine, vol. 204, no. 6, pp. 1257-1265, 2007.

[27] F. Figueiró, C. P. de Oliveira, L. S. Bergamin et al., "Methotrexate up-regulates ecto- $5^{\prime}$-nucleotidase/CD73 and reduces the frequency of T lymphocytes in the glioblastoma microenvironment," Purinergic Signal, vol. 12, no. 2, pp. 303-312, 2016.
[28] T. L. Walunas, C. Y. Bakker, and J. A. Bluestone, "CTLA-4 ligation blocks CD28-dependent T cell activation," The Journal of Experimental Medicine, vol. 183, no. 6, pp. 2541-2550, 1996.

[29] P. S. Linsley, J. A. L. Greene, W. Brady, J. Bajorath, J. A. Ledbetter, and R. Peach, "Human B7-1 (CD80) and B7-2 (CD86) bind with similar avidities but distinct kinetics to CD28 and CTLA-4 receptors," Immunity, vol. 1, no. 9, pp. 793-801, 1994.

[30] B. M. Carreno, F. Bennett, T. A. Chau et al., "CTLA-4 (CD152) can inhibit $t$ cell activation by two different mechanisms depending on its level of cell surface expression," Journal of Immunology, vol. 165, no. 3, pp. 1352-1356, 2000.

[31] C. Nakaseko, S. Miyatake, T. Iida et al., "Cytotoxic T lymphocyte antigen 4 (CTLA-4) engagement delivers an inhibitory signal through the membrane-proximal region in the absence of the tyrosine motif in the cytoplasmic tail," The Journal of Experimental Medicine, vol. 190, no. 6, pp. 765-774, 1999.

[32] T. Cinek, A. Sadra, and J. B. Imboden, "Cutting edge: tyrosine-independent transmission of inhibitory signals by CTLA-4," Journal of Immunology, vol. 164, no. 1, pp. 5-8, 2000.

[33] O. S. Qureshi, Y. Zheng, K. Nakamura et al., "Trans-endocytosis of CD80 and CD86: a molecular basis for the cellextrinsic function of CTLA-4," Science, vol. 332, no. 6029, pp. 600-603, 2011.

[34] T. Z. Hou, O. S. Qureshi, C. J. Wang et al., "A transendocytosis model of CTLA-4 function predicts its suppressive behavior on regulatory T cells," Journal of Immunology, vol. 194, no. 5, pp. 2148-2159, 2015.

[35] I. P. Sugár, J. Das, C. Jayaprakash, and S. C. Sealfon, "Multiscale modeling of complex formation and CD80 depletion during immune synapse development," Biophysical Journal, vol. 112, no. 5, pp. 997-1009, 2017.

[36] F. Bengsch, D. M. Knoblock, A. Liu, F. McAllister, and G. L. Beatty, "CTLA-4/CD80 pathway regulates $\mathrm{T}$ cell infiltration into pancreatic cancer," Cancer Immunology, Immunother$a p y$, vol. 66, no. 12, pp. 1609-1617, 2017.

[37] C. Lang, J. Wang, and L. Chen, "CD25-expressing Th17 cells mediate $\mathrm{CD}^{+} \mathrm{T}$ cell suppression in CTLA-4 dependent mechanisms in pancreatic ductal adenocarcinoma," Experimental Cell Research, vol. 360, no. 2, pp. 384-389, 2017.

[38] B. M. Olson, E. Jankowska-Gan, J. T. Becker, D. A. A. Vignali, W. J. Burlingham, and D. G. McNeel, "Human prostate tumor antigen-specific $\mathrm{CD}^{+}$regulatory T cells are inhibited by CTLA-4 or IL-35 blockade," Journal of Immunology, vol. 189, no. 12, pp. 5590-5601, 2012.

[39] P. P. C. Boor, H. J. Metselaar, S. Jonge, S. Mancham, L. J. W. van der Laan, and J. Kwekkeboom, "Human plasmacytoid dendritic cells induce $\mathrm{CD} 8^{+} \mathrm{LAG}-3^{+}$Foxp $3^{+} \mathrm{CTLA}-4^{+}$regulatory T cells that suppress allo-reactive memory T cells," European Journal of Immunology, vol. 41, no. 6, pp. 1663-1674, 2011.

[40] B. Huard, P. Gaulard, F. Faure, T. Hercend, and F. Triebel, "Cellular expression and tissue distribution of the human LAG-3-encoded protein, an MHC class II ligand," Immunogenetics, vol. 39, no. 3, pp. 213-217, 1994.

[41] C. . J. Workman, D. . S. Rice, K. . J. Dugger, C. Kurschner, and D. . A. . A. Vignali, "Phenotypic analysis of the murine CD4-related glycoprotein, CD223 (LAG-3)," European Journal of Immunology, vol. 32, no. 8, pp. 2255-2263, 2002. 
[42] B. Huard, P. Prigent, M. Tournier, D. Bruniquel, and F. Triebel, "CD4/major histocompatibility complex class II interaction analyzed with CD4- and lymphocyte activation gene-3 (LAG-3)-Ig fusion proteins," European Journal of Immunology, vol. 25, no. 9, pp. 2718-2721, 1995.

[43] S. Hannier, M. Tournier, G. Bismuth, and F. Triebel, "CD3/ TCR complex-associated lymphocyte activation gene-3 molecules inhibit CD3/TCR signaling," The Journal of Immunology, vol. 161, no. 8, pp. 4058-4065, 1998.

[44] L. Maçon-Lemaître and F. Triebel, "The negative regulatory function of the lymphocyte-activation gene-3 co-receptor (CD223) on human T cells," Immunology, vol. 115, no. 2, pp. 170-178, 2005.

[45] J. F. Grosso, C. C. Kelleher, T. J. Harris et al., "LAG-3 regulates $\mathrm{CD}^{+} \mathrm{T}$ cell accumulation and effector function in murine self- and tumor-tolerance systems," The Journal of Clinical Investigation, vol. 117, no. 11, pp. 3383-3392, 2007.

[46] M. Bettini, A. L. Szymczak-Workman, K. Forbes et al., "Cutting edge: accelerated autoimmune diabetes in the absence of LAG-3," Journal of Immunology, vol. 187, no. 7, pp. 34933498, 2011.

[47] H. Liu, Y. Wang, Q. Zeng et al., "Suppression of allograft rejection by $\mathrm{CD} 8+\mathrm{CD} 122+\mathrm{PD}-1+$ Tregs is dictated by their Fas ligand-initiated killing of effector $\mathrm{T}$ cells versus Fas-mediated own apoptosis," Oncotarget, vol. 8, no. 15, pp. 24187-24195, 2017.

[48] K. Akane, S. Kojima, T. W. Mak, H. Shiku, and H. Suzuki, "CD $8^{+} \mathrm{CD} 122^{+} \mathrm{CD} 49 \mathrm{~d}^{\text {low }}$ regulatory $\mathrm{T}$ cells maintain $\mathrm{T}$-cell homeostasis by killing activated T cells via Fas/FasL-mediated cytotoxicity," Proceedings of the National Academy of Sciences of the United States of America, vol. 113, no. 9, pp. 2460-2465, 2016.

[49] J. E. Lopes, T. R. Torgerson, L. A. Schubert et al., "Analysis of FOXP3 reveals multiple domains required for its function as a transcriptional repressor," Journal of Immunology, vol. 177, no. 5, pp. 3133-3142, 2006.

[50] L. A. Schubert, E. Jeffery, Y. Zhang, F. Ramsdell, and S. F. Ziegler, "Scurfin (FOXP3) acts as a repressor of transcription and regulates $\mathrm{T}$ cell activation," The Journal of Biological Chemistry, vol. 276, no. 40, pp. 37672-37679, 2001.

[51] S. Kanangat, P. Blair, R. Reddy et al., "Disease in the scurfy $(s f)$ mouse is associated with overexpression of cytokine genes," European Journal of Immunology, vol. 26, no. 1, pp. 161-165, 1996.

[52] P. Waterhouse, J. M. Penninger, E. Timms et al., "Lymphoproliferative disorders with early lethality in mice deficient in Ctla-4," Science, vol. 270, no. 5238, pp. 985-988, 1995.

[53] D. Fenoglio, F. Ferrera, M. Fravega et al., "Advancements on phenotypic and functional characterization of non-antigenspecific CD8+CD28- regulatory T cells," Human Immunology, vol. 69, no. 11, pp. 745-750, 2008.

[54] J. Lee, N. Park, J. Y. Park et al., "Induction of immunosuppressive $\mathrm{CD}^{+} \mathrm{CD} 25^{+} \mathrm{FOXP}^{+}$regulatory $\mathrm{T}$ cells by suboptimal stimulation with staphylococcal enterotoxin C1," Journal of Immunology, vol. 200, no. 2, pp. 669-680, 2018.

[55] S. Bézie, D. Meistermann, L. Boucault et al., "Ex vivo expanded human non-cytotoxic $\mathrm{CD}^{+} \mathrm{CD} 45 \mathrm{RC}^{\text {low/- }}$ Tregs efficiently delay skin graft rejection and GVHD in humanized mice," Frontiers in Immunology, vol. 8, 2014.

[56] C. Jochems, M. Fantini, R. I. Fernando et al., "The IDO1 selective inhibitor epacadostat enhances dendritic cell immunogenicity and lytic ability of tumor antigen-specific T cells," Oncotarget, vol. 7, no. 25, pp. 37762-37772, 2016.

[57] K. E. Balashov, S. J. Khoury, D. A. Hafler, and H. L. Weiner, "Inhibition of $\mathrm{T}$ cell responses by activated human CD8+ T cells is mediated by interferon-gamma and is defective in chronic progressive multiple sclerosis," The Journal of Clinical Investigation, vol. 95, no. 6, pp. 2711-2719, 1995.

[58] S. Tardito, S. Negrini, G. Conteduca et al., "Indoleamine 2,3 dioxygenase gene polymorphisms correlate with CD8+ Treg impairment in systemic sclerosis," Human Immunology, vol. 74, no. 2, pp. 166-169, 2013.

[59] L. Nie, W. Wu, Z. Lu, G. Zhu, and J. Liu, "CXCR3 may help regulate the inflammatory response in acute lung injury via a pathway modulated by IL-10 secreted by CD $8+$ CD122+ regulatory T cells," Inflammation, vol. 39 , no. 2, pp. 526$533,2016$.

[60] T. Inoue, Y. Asano, S. Matsuoka et al., "Distinction of mouse CD8+ suppressor effector $\mathrm{T}$ cell clones from cytotoxic $\mathrm{T}$ cell clones by cytokine production and CD45 isoforms," Journal of Immunology, vol. 150, no. 6, pp. 2121-2128, 1993.

[61] T. Hisatsune, Y. Minai, K. Nishisima et al., "A suppressive lymphokine derived from Ts clone 13G2 is IL-10," Lymphokine and Cytokine Research, vol. 11, no. 2, pp. 87-93, 1992.

[62] G. Filaci, M. Fravega, S. Negrini et al., "Nonantigen specific $\mathrm{CD}^{+} \mathrm{T}$ suppressor lymphocytes originate from $\mathrm{CD} 8^{+} \mathrm{CD} 28^{-}$ $\mathrm{T}$ cells and inhibit both T-cell proliferation and CTL function," Human Immunology, vol. 65, no. 2, pp. 142-156, 2004.

[63] S. Bézie, E. Picarda, J. Ossart et al., "IL-34 is a Tregspecific cytokine and mediates transplant tolerance," The Journal of Clinical Investigation, vol. 125, no. 10, pp. 3952-3964, 2015.

[64] R. Lindau, R. B. Mehta, G. E. Lash et al., "Interleukin-34 is present at the fetal-maternal interface and induces immunoregulatory macrophages of a decidual phenotype in vitro," Human Reproduction, vol. 33, no. 4, pp. 588-599, 2018.

[65] H. Lin, E. Lee, K. Hestir et al., "Discovery of a cytokine and its receptor by functional screening of the extracellular proteome," Science, vol. 320, no. 5877, pp. 807-811, 2008.

[66] Y. Wang, K. J. Szretter, W. Vermi et al., "IL-34 is a tissuerestricted ligand of CSF1R required for the development of Langerhans cells and microglia," Nature Immunology, vol. 13, no. 8, pp. 753-760, 2012.

[67] X. Chen, S. Hao, Z. Zhao et al., "Interleukin 35: inhibitory regulator in monocyte-derived dendritic cell maturation and activation," Cytokine, vol. 108, pp. 43-52, 2018.

[68] R. Tinoco, V. Alcalde, Y. Yang, K. Sauer, and E. I. Zuniga, "Cell-intrinsic transforming growth factor- $\beta$ signaling mediates virus-specific $\mathrm{CD} 8^{+} \mathrm{T}$ cell deletion and viral persistence in vivo," Immunity, vol. 31, no. 1, pp. 145-157, 2009.

[69] M. L. Chen, B. S. Yan, D. Kozoriz, and H. L. Weiner, "Novel $\mathrm{CD}^{+}$Treg suppress EAE by TGF- $\beta$ - and IFN- $\gamma$-dependent mechanisms," European Journal of Immunology, vol. 39, no. 12, pp. 3423-3435, 2009.

[70] L. Zhang, A. M. Bertucci, R. Ramsey-Goldman, R. K. Burt, and S. K. Datta, "Regulatory T cell (Treg) subsets return in patients with refractory lupus following stem cell transplantation, and TGF- $\beta$-producing $\mathrm{CD}^{+}{ }^{+}$Treg cells are associated with immunological remission of lupus," Journal of Immunology, vol. 183, no. 10, pp. 6346-6358, 2009.

[71] Y. H. Ahn, S. O. Hong, J. H. Kim et al., "The siRNA cocktail targeting interleukin 10 receptor and transforming growth 
factor- $\beta$ receptor on dendritic cells potentiates tumour antigen-specific $\mathrm{CD}^{+} \mathrm{T}$ cell immunity," Clinical and Experimental Immunology, vol. 181, no. 1, pp. 164-178, 2015.

[72] S. Zhang, X. Ke, S. Zeng et al., "Analysis of CD8 ${ }^{+}$Treg cells in patients with ovarian cancer: a possible mechanism for immune impairment," Cellular \& Molecular Immunology, vol. 12, no. 5, pp. 580-591, 2015.

[73] J. J. Goronzy, J. W. Fulbright, C. S. Crowson, G. A. Poland, W. M. O'Fallon, and C. M. Weyand, "Value of immunological markers in predicting responsiveness to influenza vaccination in elderly individuals," Journal of Virology, vol. 75, no. 24, pp. 12182-12187, 2001.

[74] D. N. Posnett, R. Sinha, S. Kabak, and C. Russo, "Clonal populations of $\mathrm{T}$ cells in normal elderly humans: the T cell equivalent to "benign monoclonal gammapathy"," The Journal of Experimental Medicine, vol. 179, no. 2, pp. 609-618, 1994.

[75] N. Khan, N. Shariff, M. Cobbold et al., "Cytomegalovirus seropositivity drives the CD8 T cell repertoire toward greater clonality in healthy elderly individuals," Journal of Immunology, vol. 169, no. 4, pp. 1984-1992, 2002.

[76] D. N. Posnett, J. W. Edinger, J. S. Manavalan, C. Irwin, and G. Marodon, "Differentiation of human CD8 T cells: implications for in vivo persistence of $\mathrm{CD} 8^{+} \mathrm{CD} 28^{-}$cytotoxic effector clones," International Immunology, vol. 11, no. 2, pp. 229241, 1999.

[77] R. B. Effros, R. Allsopp, C. P. Chiu et al., "Shortened telomeres in the expanded CD28-CD8+ cell subset in HIV disease implicate replicative senescence in HIV pathogenesis," AIDS, vol. 10, no. 8, pp. F17-F22, 1996.

[78] U. J. Scheuring, H. Sabzevari, and A. N. Theofilopoulos, "Proliferative arrest and cell cycle regulation in $\mathrm{CD}^{+} \mathrm{CD} 28^{-}$versus $\mathrm{CD}^{+} \mathrm{CD} 28^{+} \mathrm{T}$ cells," Human Immunology, vol. 63, no. 11, pp. 1000-1009, 2002.

[79] Q. Liu, H. Zheng, X. Chen et al., "Human mesenchymal stromal cells enhance the immunomodulatory function of CD $8^{+} \mathrm{CD} 28^{-}$regulatory $\mathrm{T}$ cells," Cellular \& Molecular Immunology, vol. 12, no. 6, pp. 708-718, 2015.

[80] S. Ceeraz, C. Hall, E. H. Choy, J. Spencer, and V. M. Corrigall, "Defective $\mathrm{CD} 8^{+} \mathrm{CD} 28^{-}$regulatory $\mathrm{T}$ cell suppressor function in rheumatoid arthritis is restored by tumour necrosis factor inhibitor therapy," Clinical and Experimental Immunology, vol. 174, no. 1, pp. 18-26, 2013.

[81] X. Y. He, L. Xiao, H. B. Chen et al., "T regulatory cells and Th1/Th2 cytokines in peripheral blood from tuberculosis patients," European Journal of Clinical Microbiology \& Infectious Diseases, vol. 29, no. 6, pp. 643-650, 2010.

[82] T. Boettler, E. Panther, B. Bengsch et al., "Expression of the interleukin-7 receptor alpha chain (CD127) on virusspecific $\mathrm{CD}^{+} \mathrm{T}$ cells identifies functionally and phenotypically defined memory $\mathrm{T}$ cells during acute resolving hepatitis B virus infection," Journal of Virology, vol. 80, no. 7, pp. 3532-3540, 2006.

[83] M. J. Fuller, D. A. Hildeman, S. Sabbaj et al., "Cutting edge: emergence of $\mathrm{CD} 127^{\text {high }}$ functionally competent memory $\mathrm{T}$ cells is compromised by high viral loads and inadequate T cell help," Journal of Immunology, vol. 174, no. 10, pp. 59265930, 2005.

[84] K. M. Huster, V. Busch, M. Schiemann et al., "Selective expression of IL-7 receptor on memory T cells identifies early CD40L-dependent generation of distinct $\mathrm{CD}^{+}$memory $\mathrm{T}$ cell subsets," Proceedings of the National Academy of Sciences of the United States of America, vol. 101, no. 15, pp. 56105615, 2004.

[85] W. Liu, A. L. Putnam, Z. Xu-yu et al., "CD127 expression inversely correlates with FoxP3 and suppressive function of human $\mathrm{CD}^{+} \mathrm{T}$ reg cells," The Journal of Experimental Medicine, vol. 203, no. 7, pp. 1701-1711, 2006.

[86] U. Bjarnadottir, A. L. Lemarquis, S. Halldorsdottir, J. Freysdottir, and B. R. Ludviksson, "The suppressive function of human $\mathrm{CD}^{+}$iTregs is inhibited by IL-1 $\beta$ and TNF $\alpha$," Scandinavian Journal of Immunology, vol. 80, no. 5, pp. 313322, 2014.

[87] M. L. Hermiston, Z. Xu, and A. Weiss, "CD45: a critical regulator of signaling thresholds in immune cells," Annual Review of Immunology, vol. 21, no. 1, pp. 107-137, 2003.

[88] G. P. Spickett, M. R. Brandon, D. W. Mason, A. F. Williams, and G. R. Woollett, "MRC OX-22, a monoclonal antibody that labels a new subset of $\mathrm{T}$ lymphocytes and reacts with the high molecular weight form of the leukocyte-common antigen," The Journal of Experimental Medicine, vol. 158, no. 3, pp. 795-810, 1983.

[89] E. Xystrakis, I. Bernard, A. S. Dejean, T. Alsaati, P. Druet, and A. Saoudi, "Alloreactive CD4 T lymphocytes responsible for acute and chronic graft-versus-host disease are contained within the CD45RC high but not the CD45RC ${ }^{\text {low }}$ subset," European Journal of Immunology, vol. 34, no. 2, pp. 408417, 2004.

[90] E. Xystrakis, A. S. Dejean, I. Bernard et al., "Identification of a novel natural regulatory CD8 T-cell subset and analysis of its mechanism of regulation," Blood, vol. 104, no. 10, pp. 32943301, 2004.

[91] F. Powrie and D. Mason, "OX-22high CD4+ T cells induce wasting disease with multiple organ pathology: prevention by the OX-22low subset," The Journal of Experimental Medicine, vol. 172, no. 6, pp. 1701-1708, 2018.

[92] L. Ordonez, I. Bernard, F.-E. L'Faqihi-Olive, J. W. C. Tervaert, J. Damoiseaux, and A. Saoudi, "CD45RC isoform expression identifies functionally distinct $\mathrm{T}$ cell subsets differentially distributed between healthy individuals and AAV patients," PLoS One, vol. 4, no. 4, article e5287, 2009.

[93] M. C. Boer, C. Prins, K. E. van Meijgaarden, J. T. van Dissel, T. H. M. Ottenhoff, and S. A. Joosten, "Mycobacterium bovis BCG vaccination induces divergent proinflammatory or regulatory $\mathrm{T}$ cell responses in adults," Clinical and Vaccine Immunology, vol. 22, no. 7, pp. 778-788, 2015.

[94] M. C. Boer, K. E. van Meijgaarden, S. A. Joosten, and T. H. M. Ottenhoff, "CD8 ${ }^{+}$regulatory $\mathrm{T}$ cells, and not $\mathrm{CD} 4^{+} \mathrm{T}$ cells, dominate suppressive phenotype and function after in vitro live Mycobacterium bovis-BCG activation of human cells," PLoS One, vol. 9, no. 4, article e94192, 2014.

[95] N. Alatrakchi, C. S. Graham, H. J. J. van der Vliet, K. E. Sherman, M. A. Exley, and M. J. Koziel, "Hepatitis C virus $(\mathrm{HCV})$-specific $\mathrm{CD}^{+}$cells produce transforming growth factor $\beta$ that can suppress $\mathrm{HCV}$-specific T-cell responses," Journal of Virology, vol. 81, no. 11, pp. 5882-5892, 2007.

[96] I. Tóth, A. Q. le, P. Hartjen et al., "Decreased frequency of $\mathrm{CD} 3^{+} \mathrm{CD} 8^{+} \mathrm{T}$ cells of HIV-infected patients correlates with immune activation and T cell exhaustion," Journal of Leukocyte Biology, vol. 94, no. 4, pp. 551-561, 2013.

[97] D. Fenoglio, C. Dentone, A. Signori et al., " $\mathrm{CD} 8^{+-}$ $\mathrm{CD} 28^{-} \mathrm{CD} 127^{\mathrm{lo}} \mathrm{CD} 39^{+}$regulatory T-cell expansion: a new possible pathogenic mechanism for HIV infection," Journal 
of Allergy and Clinical Immunology, vol. 141, no. 6, pp. 22202233.e4, 2018.

[98] I. Popescu, C. Macedo, K. Abu-Elmagd et al., "EBV-specific $\mathrm{CD}^{+} \mathrm{T}$ cell reactivation in transplant patients results in expansion of $\mathrm{CD}^{+}$type- 1 regulatory T cells," American Journal of Transplantation, vol. 7, no. 5, pp. 1215-1223, 2007.

[99] S. Gautam, R. Kumar, N. Singh et al., "CD8 T cell exhaustion in human visceral leishmaniasis," The Journal of Infectious Diseases, vol. 209, no. 2, pp. 290-299, 2014.

[100] S. Ganguly, D. Mukhopadhyay, N. K. Das et al., "Enhanced lesional Foxp3 expression and peripheral anergic lymphocytes indicate a role for regulatory $\mathrm{T}$ cells in Indian postkala-azar dermal leishmaniasis," The Journal of Investigative Dermatology, vol. 130, no. 4, pp. 1013-1022, 2010.

[101] N. Najafian, T. Chitnis, A. D. Salama et al., "Regulatory functions of $\mathrm{CD}^{+} \mathrm{CD} 28^{-} \mathrm{T}$ cells in an autoimmune disease model," The Journal of Clinical Investigation, vol. 112, no. 7, pp. 1037-1048, 2003.

[102] P. Yu, R. N. Bamford, and T. A. Waldmann, "IL-15-dependent $\mathrm{CD}^{+} \mathrm{CD} 122^{+} \mathrm{T}$ cells ameliorate experimental autoimmune encephalomyelitis by modulating IL-17 production by $\mathrm{CD}^{+} \mathrm{T}$ cells," European Journal of Immunology, vol. 44, no. 11, pp. 3330-3341, 2014.

[103] G. Z. Liu, L. B. Fang, P. Hjelmström, and X. G. Gao, "Increased CD8+ central memory T cells in patients with multiple sclerosis," Multiple Sclerosis, vol. 13, no. 2, pp. 149-155, 2007.

[104] C. Aristimuño, C. de Andrés, M. Bartolomé et al., "IFN $\beta$-1a therapy for multiple sclerosis expands regulatory $\mathrm{CD}^{+} \mathrm{T}$ cells and decreases memory $\mathrm{CD}^{+}$subset: a longitudinal 1year study," Clinical Immunology, vol. 134, no. 2, pp. 148157, 2010.

[105] L. Zhang, A. M. Bertucci, R. Ramsey-Goldman, E. R. HarshaStrong, R. K. Burt, and S. K. Datta, "Major pathogenic steps in human lupus can be effectively suppressed by nucleosomal histone peptide epitope-induced regulatory immunity," Clinical Immunology, vol. 149, no. 3, pp. 365-378, 2013.

[106] F. Bernuzzi, D. Fenoglio, F. Battaglia et al., "Phenotypical and functional alterations of CD8 regulatory $\mathrm{T}$ cells in primary biliary cirrhosis," Journal of Autoimmunity, vol. 35, no. 3, pp. 176-180, 2010.

[107] A. Parodi, F. Battaglia, F. Kalli et al., "CD39 is highly involved in mediating the suppression activity of tumor-infiltrating CD8+ T regulatory lymphocytes," Cancer Immunology, Immunotherapy, vol. 62, no. 5, pp. 851-862, 2013.

[108] G. Filaci, D. Fenoglio, M. Fravega et al., "CD8 ${ }^{+} \mathrm{CD} 28^{-}$T regulatory lymphocytes inhibiting $\mathrm{T}$ cell proliferative and cytotoxic functions infiltrate human cancers," Journal of Immunology, vol. 179, no. 7, pp. 4323-4334, 2007.

[109] C. Chen, D. Chen, Y. Zhang et al., "Changes of CD4+CD25 +FOXP3+ and CD8+CD28- regulatory $\mathrm{T}$ cells in non-small cell lung cancer patients undergoing surgery," International Immunopharmacology, vol. 18, no. 2, pp. 255-261, 2014.

[110] N. Chaput, S. Louafi, A. Bardier et al., "Identification of $\mathrm{CD}^{+} \mathrm{CD} 25^{+} \mathrm{Foxp}^{+}$suppressive $\mathrm{T}$ cells in colorectal cancer tissue," Gut, vol. 58, no. 4, pp. 520-529, 2009.

[111] Y. Kiniwa, Y. Miyahara, H. Y. Wang et al., "CD8 ${ }^{+}$Foxp3 $^{+}$ regulatory $\mathrm{T}$ cells mediate immunosuppression in prostate cancer," Clinical Cancer Research, vol. 13, no. 23, pp. 69476958, 2007.
[112] F. P. Canale, M. C. Ramello, N. Núñez et al., "CD39 expression defines cell exhaustion in tumor-infiltrating $\mathrm{CD}^{+} \mathrm{T}$ cells," Cancer Research, vol. 78, no. 1, pp. 115-128, 2018.

[113] X. L. Li, S. Menoret, S. Bezie et al., "Mechanism and localization of CD8 regulatory T cells in a heart transplant model of tolerance," Journal of Immunology, vol. 185, no. 2, pp. 823$833,2010$.

[114] J. Heinrichs, J. Li, H. Nguyen et al., "CD8 ${ }^{+}$Tregs promote GVHD prevention and overcome the impaired GVL effect mediated by CD $4^{+}$Tregs in mice," OncoImmunology, vol. 5, no. 6, article e1146842, 2016.

[115] J. Zheng, Y. Liu, Y. Liu et al., "Human $\mathrm{CD}^{+}$regulatory T cells inhibit GVHD and preserve general immunity in humanized mice," Science Translational Medicine, vol. 5, no. 168, article 168ra9, 2013.

[116] P. G. Hemmati, T. H. Terwey, P. le Coutre et al., "A modified EBMT risk score predicts the outcome of patients with acute myeloid leukemia receiving allogeneic stem cell transplants," European Journal of Haematology, vol. 86, no. 4, pp. 305-316, 2011.

[117] L. M. Ball, R. M. Egeler, and on behalf of the EBMT Paediatric Working Party, "Acute GvHD: pathogenesis and classification," Bone Marrow Transplantation, vol. 41, pp. S58-S64, 2008.

[118] E. Goulmy, R. Schipper, J. Pool et al., "Mismatches of minor histocompatibility antigens between HLA-identical donors and recipients and the development of graft-versus-host disease after bone marrow transplantation," The New England Journal of Medicine, vol. 334, no. 5, pp. 281-285, 1996.

[119] K. C. Hsu, T. Gooley, M. Malkki et al., "KIR ligands and prediction of relapse after unrelated donor hematopoietic cell transplantation for hematologic malignancy," Biology of Blood and Marrow Transplantation, vol. 12, no. 8, pp. 828-836, 2006.

[120] J. D. Goldberg, J. Zheng, R. Ratan et al., "Early recovery of T-cell function predicts improved survival after T-cell depleted allogeneic transplant," Leukemia \& Lymphoma, vol. 58, no. 8, pp. 1859-1871, 2017.

[121] R. Reshef, A. P. Huffman, A. Gao et al., "High graft CD8 cell dose predicts improved survival and enables better donor selection in allogeneic stem-cell transplantation with reduced-intensity conditioning," Journal of Clinical Oncology, vol. 33, no. 21, pp. 2392-2398, 2015.

[122] G. L. Beatty, J. S. Smith, R. Reshef et al., "Functional unresponsiveness and replicative senescence of myeloid leukemia antigen-specific $\mathrm{CD}^{+} \mathrm{T}$ cells after allogeneic stem cell transplantation," Clinical Cancer Research, vol. 15, no. 15, pp. 4944-4953, 2009.

[123] I. Avivi, D. Stroopinsky, J. M. Rowe, and T. Katz, "A subset of $\mathrm{CD}^{+} \mathrm{T}$ cells acquiring selective suppressive properties may play a role in GvHD management," Transplant Immunology, vol. 28, no. 1, pp. 57-61, 2013.

[124] A. Gutiérrez-Hoya, R. López-Santiago, J. Vela-Ojeda et al., "Role of CD8 regulatory T cells versus Tc1 and Tc17 cells in the development of human graft-versus-host disease," Journal of Immunology Research, vol. 2017, Article ID 1236219, 11 pages, 2017.

[125] A. J. Beres, D. Haribhai, A. C. Chadwick, P. J. Gonyo, C. B. Williams, and W. R. Drobyski, "CD8 ${ }^{+}$Foxp $^{+}$regulatory T cells are induced during graft-versus-host disease and mitigate disease severity," Journal of Immunology, vol. 189, no. 1, pp. 464-474, 2012. 
[126] R. J. Robb, K. E. Lineburg, R. D. Kuns et al., "Identification and expansion of highly suppressive $\mathrm{CD} 8^{+} \mathrm{FoxP}^{+}$regulatory $\mathrm{T}$ cells after experimental allogeneic bone marrow transplantation," Blood, vol. 119, no. 24, pp. 5898-5908, 2012.

[127] H. Nikoueinejad, A. Amirzargar, A. Sarrafnejad et al., "Dynamic changes of regulatory $\mathrm{T}$ cell and dendritic cell subsets in stable kidney transplant patients: a prospective analysis," Iranian Journal of Kidney Diseases, vol. 8, no. 2, pp. 130-138, 2014.

[128] E. Picarda, S. Bézie, V. Venturi et al., "MHC-derived allopeptide activates TCR-biased CD8-Tregs and suppresses organ rejection," The Journal of Clinical Investigation, vol. 124, no. 6, pp. 2497-2512, 2014.

[129] E. Picarda, S. Bézie, L. Boucault et al., "Transient antibody targeting of CD45RC induces transplant tolerance and potent antigen-specific regulatory T cells," JCI Insight, vol. 2, no. 3, article e90088, 2017.

[130] G. Li, A. T. Larregina, R. T. Domsic et al., "Skin-resident effector memory $\mathrm{CD} 8^{+} \mathrm{CD} 28^{-} \mathrm{T}$ cells exhibit a profibrotic phenotype in patients with systemic sclerosis," The Journal of Investigative Dermatology, vol. 137, no. 5, pp. 1042-1050, 2017.

[131] A. U. Engela, C. C. Baan, N. H. R. Litjens et al., "Mesenchymal stem cells control alloreactive $\mathrm{CD} 8^{+} \mathrm{CD} 28^{-} \mathrm{T}$ cells," Clinical and Experimental Immunology, vol. 174, no. 3, pp. 449-458, 2013. 


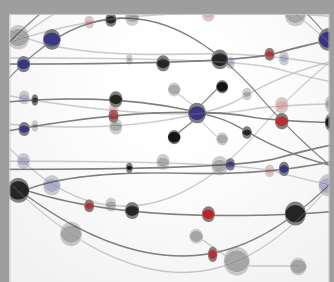

The Scientific World Journal
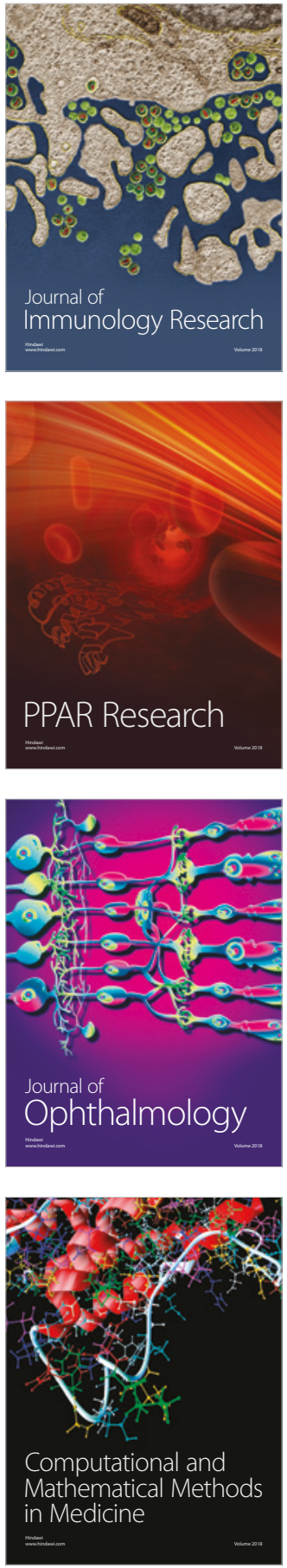

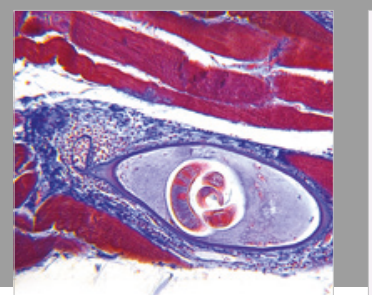

Gastroenterology Research and Practice

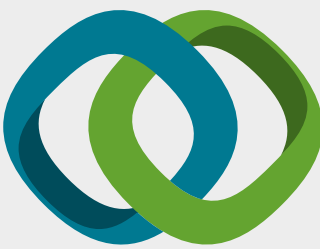

\section{Hindawi}

Submit your manuscripts at

www.hindawi.com
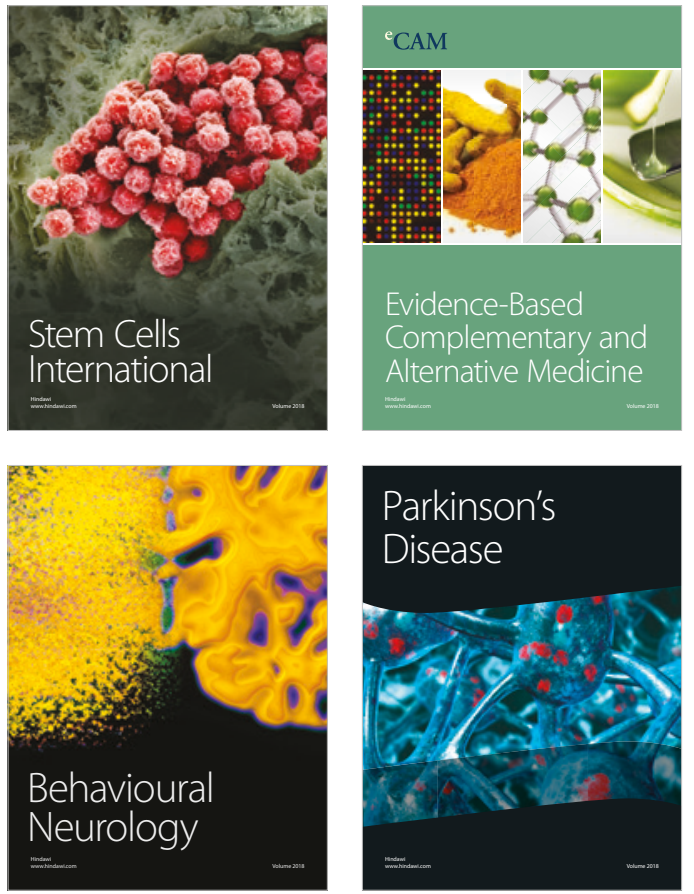

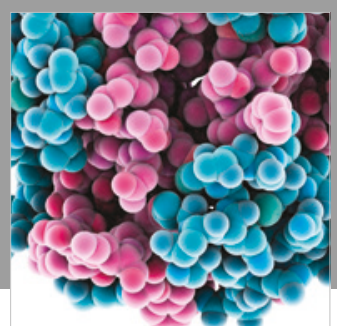

ournal of

Diabetes Research

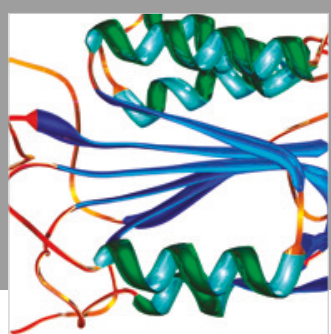

Disease Markers
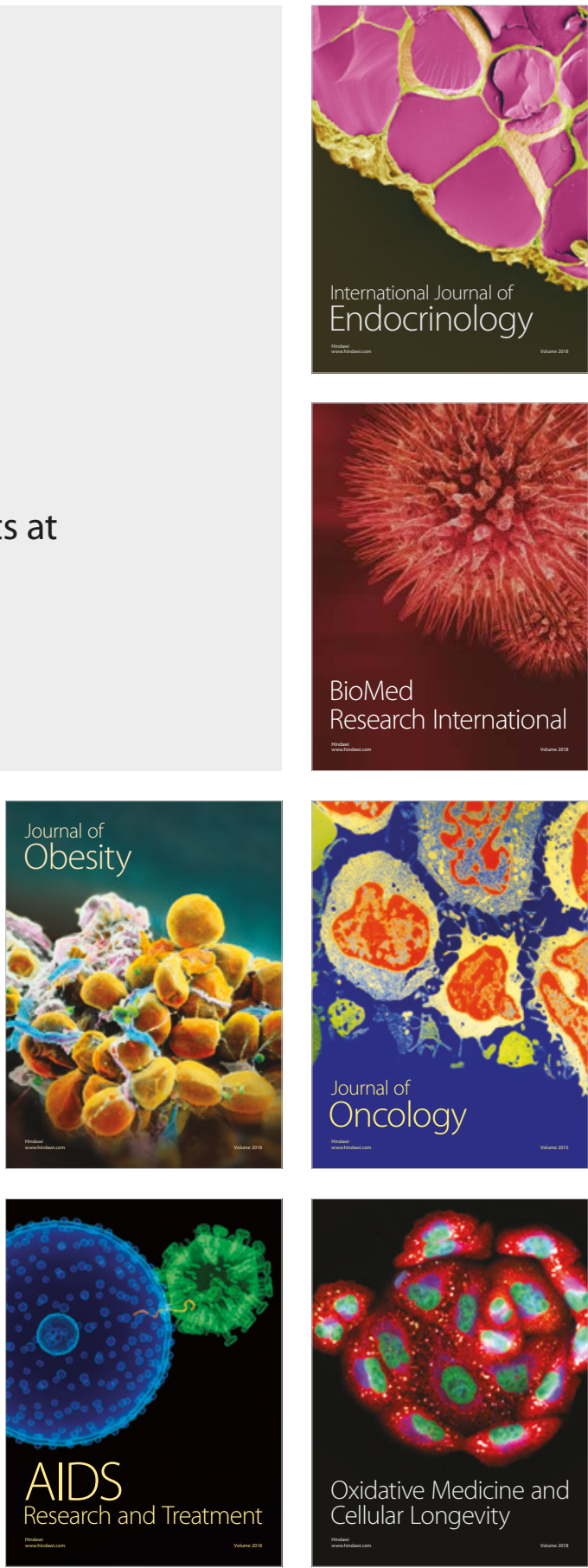